\title{
THE DEVELOPMENT OF THE CRANIAL AND SPINAL NERVES IN THE OCCIPITAL REGION OF THE HUMAN EMBRYO.
}

\author{
BY \\ GEORGE L. STREETER, M. D. \\ Instructor in Anatomy, Johns Hopkins University. \\ With 4 Plates and 14 Text Figures.
}

The following paper reports the results of a study of the morphology of the ninth, tenth, eleventh, and twelfth cranial and the upper cervical nerves, together with their ganglia, in a series of human embryos. It includes a description of all the stages in the development of these structures from the time at which they can first be definitely outlined from the surrounding mesodermal tissue up to the time they have reached adult conditions. This work was made possible through the kindness of Prof. O. Hertwig, Prof. His, and Prof. Mall, who gave the writer access to their valuable embryo collections for the purposes of this study. For this courtesy the writer takes advantage of the present opportunity to express his appreciation. Acknowledgment is also to be made to Prof. Gage, whose Buxton embryo is included in the series studied.

The ultimate histogenesis of the nerve elements, a question which has recently been thoroughly gone over by Harrison, 01, and Bardeen, 03, will not be taken up. In the earliest stage where reconstruction was possible the right and left divisions of the ganglion crest have migrated ventro-laterally along the side of the neural tube, and are about to form secondary attachments to it. Fibroblast formation is at this time well under way, and peripheral fibre paths are beginning to become definite. It is the consideration of the size, form, and relation of these paths and the associated ganglion cell masses, in their different stages of growth, toward which attention has been directed.

The results of this study are tabulated at the end of the paper; but special mention should be made of the eleventh cranial nerve. In tracing out its early history it becomes more than ever apparent that it is absolutely similar and continuous with the tenth or vagus nerve. In the embryo these exist, not as two independent cranial nerves, but rather as parts of a single structure, each part possessing mixed motor and Amarican Journal of ANatomy.-Vol. IV. 
sensory roots with root ganglia derived from the same ganglion crest. As the development progresses the cranial end of this complex becomes predominantly sensory and the caudal end predominantly motor, and also more spread out which gives rise to a difference in the appearance of the two portions in the adult, and has resulted in their being considered as two independent structures.

That such a relation between the tenth and eleventh cranial nerves exists is not a new idea, but was long ago suggested by the work of $H i s$, 88 , on the human embryo, though this investigator did not work with sufficiently young stages to make the evidence conclusive. The theory has since then been supported by the work of Fürbringer, 97, and Lubosch, 99, who believe that phylogenetically the tenth and eleventh nerves cannot be separated. Chiarugi, 90, however, from the comparative embryology of these structures, concludes that the eleventh is not a part of the tenth, but is a nerve for itself which results from the differentiation of the nucleus of origin of the ventral roots into median and lateral divisions; the latter rootlets losing their segmental distribution take a new course and depart obliquely through the cranium as an independent nerve. Anothel view regarding these nerves is offered by Minot, 92. He suggests that a modification may have occurred in the motor fibres of the dorsal roots of the hypoglossus, by.which these motor fibres, following the abortion of the ganglia, no longer join the ventral roots of the twelfth, but turn forward to join the vagus thereby forming the trunk of the accessory nerve. Since the work of His, 88, and $\mathrm{Mall}, 91$, on the human embryo, further details in the development of the tenth and eleventh nerves in other mammals have been supplied in the well known papers of Froriep, 82, 85, and 01, and by the work of Robinson, 92, and Lewis, 03. The latter two give us a more accurate description of the so-called ganglionic commissure, than had before existed; although they failed to recognize the full significance of these ganglia and their relation to the precervical ganglia of Froriep.

The comparative morphology of the occipital nerves, particularly with regard to their bearing on the segmental origin of the head, has been the subject of much speculation, ever since Gegenbaur, 72, published his work on the selachian head. The charge may perhaps be justly made that more space in the literature is given to theories and discussions concerning these structures than to actual observations on their comparative and embryological anatomy. This subject will be briefly treated under the heading comparative morphology. It will be emphasized there that the ganglia of the trunks of the ninth and tenth (gang. petrosum and gang. nodosum) are branchio-meric and largely independent of the 
ganglia of the roots. The latter ganglia though not segmental more closely resemble the spinal ganglia; the attempt however to reduce the cranial nerves to a spinal nerve type is deprecated. Some such hypothesis as was long ago suggested by Balfour, 76, is much easier of application. This investigator supposed the head and trunk to have become differentiated from each other when there was only a mixed motor and sensory posterior root present and no ventral root, as was then supposed to be the case in the amphioxus. Since then it has been found (Ransom and Thompson, 86, Hatscheck, 92, Dogiel, 03) that the amphioxus and cyclostomes have ventral, purely motor, roots. These do not arise from the cord at the same level with, nor do they join, the dorsal roots. The two might be spoken of as ventral and dorsal nerves. If then Balfour's hypothesis were modified to fit with our present knowledge, it could be stated as follows: The head and trunk nerves were differentiated from each other at a time when there existed mixed motor and sensory dorsal roots and pure motor ventral roots. These ventral and dorsal roots did not then arise from the neural tube at corresponding levels, and were independent of each other. In the spinal region of higher vertebrates a modification has occurred, by which the dorsal and ventral roots have become strictly segmentally arranged, and have joined in pairs, each pair forming a common nerve, which is situated median to the myotome. In the head region the nerves have retained the primitive type; the dorsal roots still contain a good proportion of motor fibres, and are situated beneath the epidermis and outside of the myotomes. They are not segmentally arranged and do not join with the ventral roots to form common nerves, but form a system of separate ventral and dorsal (lateral) nerves.

Material and METHons.-The elements of the peripheral nervous system do not reach a degree of differentiation, which is sufficient for reconstruction, until toward the end of the third week. From then changes in the form and relation continue until the third month, when the structures have practically reached the condition found in the adult, and development may be considered as completed. The various stages in their growth were thus found to be covered by the embryos listed in the following table (page 86). Their ages have been determined by use of Mall's rule (Mall, 03), i. e., the age in days equals the square root of the product of the length times one hundred.

It was found that the ganglion masses and fibre paths could be satisfactorily identified and traced by means of profile reconstructions. This procedure was made use of with all embryos, with the exception of one at a late stage which was large enough for dissection. The details adopted 
in its application consisted in making enlarged drawings of the sections, usually fifty diameters, with a projection apparatus or camera lucida, upon separate sheets of transparent paper. Paraffined wrapping paper is serviceable and inexpensive, better than this, being stronger and more transparent, is the "process" paper, used in Germany as "butter-brodt papier" and in this country in packing tobacco. When the drawings were completed, the sheets. were piled so that adjacent sections were accurately fitted over each other. A vertical line for reconstruction was then established by marking upon each sheet two lines perpendicular to each other, forming a series of crosses which exactly superimposed throughout the entire pile. The individual sections were then plotted off on $\mathrm{mm}$. paper by fitting the crosses to a chosen perpendicular line, the distance between the sections being determined by the thickness of the sections and the enlargement of the drawings in the usual way. Many of these reconstructions are diagrammatically shown as text figures

TABLE OF EMBRYOS STUDIED.

\begin{tabular}{|c|c|c|c|c|c|c|c|c|}
\hline \multirow{2}{*}{\multicolumn{2}{|c|}{$\begin{array}{l}\text { Length. } \\
4.0 \mathrm{~mm} \text {. }\end{array}$}} & \multirow{2}{*}{\multicolumn{2}{|c|}{$\begin{array}{c}\text { Age. } \\
20 \text { days. }\end{array}$}} & \multicolumn{2}{|c|}{ Source. } & \multirow{2}{*}{$\begin{array}{l}\text { No. } \\
137\end{array}$} & \multicolumn{2}{|r|}{ Reconstruction. } \\
\hline & & & & Hertwig & Collection. & & Profile, & one side. \\
\hline 4.3 & " & 20 & $\therefore$ & Mall & “ & 148 & “ & both sides. \\
\hline 6.9 & ‘ & 26 & 6 & His & " & Br3 & " & $a$ \\
\hline 7.0 & $" 4$ & 26 & “ & Mall & * & 2 & 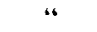 & one side. \\
\hline 7.0 & $"$ & 26 & 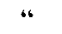 & Gage & "b & Buxton & $" 6$ & $" \quad "$ \\
\hline 10.0 & $" 4$ & 31 & "6 & Mall & $\because 6$ & 114 & " & $"$ \\
\hline 10.2 & 16 & 31 & “ & His & 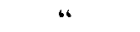 & KO & $"$ & both sides. \\
\hline 10.0 & $\because$ & 31 & 4 & His & "6 & Dl & $\because$ & one side. \\
\hline 13.8 & $"$ & 37 & “ & Hertwig & “ & 67 & “" & both sides. \\
\hline 14.0 & $"$ & 37 & ab & Mall & “ & 144 & 4 & " ", wax plate. \\
\hline 17.5 & $\star *$ & 41 & 4 & His & $\omega$ & $\mathbf{F M}$ & ، & one side. \\
\hline 30.0 & “ & 54 & ab & Hertwig & "6 & 161 & 6 & $\bullet$ \\
\hline 65.0 & " & 81 & “ & Mall & 4 & $\ldots$ & Dissect & ion. \\
\hline
\end{tabular}

(Figs. 1-12), in which fibre masses are represented by lines and ganglion cell masses by dots. The same enlargement is used in all of these so that the actual increase in size may be readily seen by comparing them.

In order to reproduce the third dimension a clay model was made of a $4.3 \mathrm{~mm}$. embryo, and a wax plate reconstruction of a $14.0 \mathrm{~mm}$. embryo. Drawings of these are reproduced in Plates I and II.

Following the suggestion of Dr. Bardeen much assistance was obtained in studying these structures by making dissections of pig embryos for comparison. It was possible in this way to control the various stages from $8.0 \mathrm{~mm}$. upward. In making such a comparison it was found, however, that the ratio between the length of the pig and the development of its nervous system does not exactly correspond to that of the human. The development of the nervous system of the latter is somewhat more 
rapid; for example, a $14.0 \mathrm{~mm}$. human embryo shows a stage found in the 18.0 to $20.0 \mathrm{~mm}$. pig embryo. The preparation of these dissections was facilitated by the use of the following method: The entire embryo is mordanted for several hours in a solution of potassium bichromate 2.5 per cent, and glacial acetic acid 10 per cent, after which it is rinsed in water and brought into 80 per cent alcohol. The embryo, after a few minutes dehydration in absolute alcohol, is then attached with a drop of thick celloidin to an isinglass strip, previously coated with thin celloidin. Mica or isinglass is used because it can be easily cut to any desired size. By smoking it, before the celloidin coat, it is possible to write any desired label on it, and the black serves as a good background for the embryo. The whole is then hardened for a short time 80 per cent alcohol, and it is then ready for dissection. In order to hold the embryo during dissection the isinglass strip on which the embryo is mounted is clamped to a stage which is made by fastening a glass slide with balsam to one of the facets of a cut-glass polyhedral paper-weight. Such a stage is steady and can be placed in any desired plane. With the embryo firmly mounted in this way the dissection is made under alcohol with a binocular microscope.

\section{Description of Embryos at Different Stages.}

Embryos of About Three Weeks.

Hertwig Collection, No. 134........... $4.0 \mathrm{~mm}$.

Mall Collection, No. $148 \ldots \ldots \ldots \ldots \ldots \ldots 4.3 \mathrm{~mm}$.

(See Figs. 1, 2, 3, and Plate I.)

By the twentieth day the structures have become definite enough in outline to permit of reconstruction. At this stage the ganglion crest of the after-brain and spinal cord has divided longitudinally into right and left halves, each of which has migrated ventro-laterally along the neural tube and forms a flattened cellular band extending caudalwards from the anditory vesicle along the lateral border of the tube to its extreme tip.

That part of the crest which corresponds to the spinal cord consists of compactly grouped cells which are so arranged as to present a flattened continuous portion or dorsal bridge, the dorsal border of which is rather smooth and sharply outlined, and shows no connection with the neural tube. There are as yet no dorsal nerve roots. Projecting ventralward from this bridge is a series of rounded segmental clumps of cells which form the primitive spinal ganglia. These end diffusely among the developing fibres of the ventral roots. The ventral border of the ganglionic crest is ill-defined in contrast to the dorsal edge of the bridge of the crest. 
At this time the fibres of the ventral roots of the spinal nerves are gathered into loose bundles and can be traced a short distance in the

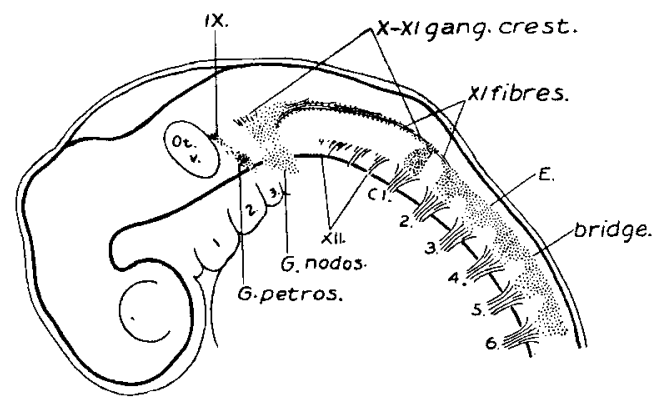

FIG. 1. Reconstruction of peripheral nerves in three weeks human embryo, $4.0 \mathrm{~mm}$. long, Hertwig collection No. 137. Enlarged 16.7 diams.

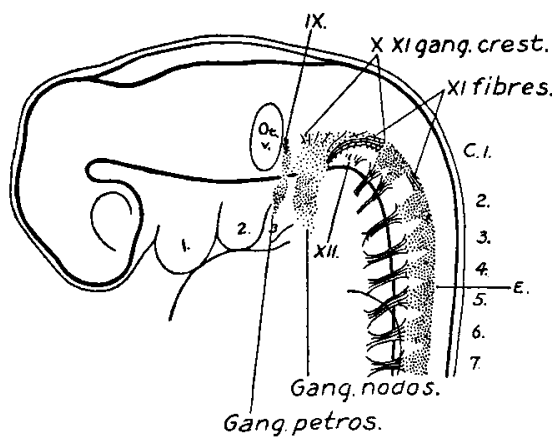

Fig. 2. Reconstruction of peripheral nerves in three weeks human embryo, $4.3 \mathrm{~mm}$. long, Mall collection No. 148. Enlarged 16.7 diams.

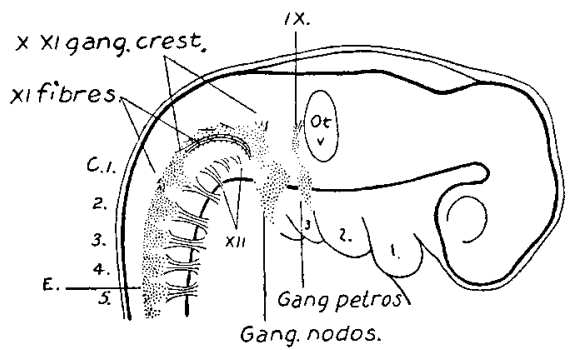

FIG. 3. Reconstruction of right side of same embryo shown in fig. 2.

mesoderm. Among them are many of the so-called sheath cell nuclei. Owing to the fact that the fibres of the ventral roots run through the 
ventral part of the spinal ganglia it is impossible to determine the presence or absence of fibroblasts belonging to these ganglia.

The first, or most oral, of the spinal ganglia exhibits special characteristics. It is separated from the second ganglion by an enlarged interval, and it is usually smaller and more slender than the other ganglia. In some cases it consists of a very small clump of cells showing no tendency to unite with its ventral root, or it may be absent completely. On the other hand it may be accompanied by additional ganglionic cell-masses representing the occipital ganglia, found by Froriep, 82, to be constant in the sheep. In one case (Fig. 2) the ganglion is divided ventrally into two clumps of equal size, corresponding to a likewise divided ventral root. The more oral of these two may therefore be considered as a persistent occipital nerve and ganglion.

That part of the ganglion crest which is situated lateral to the afterbrain differs from the spinal portion of the crest in that it consists of more loosely arranged cells, and as a whole it is flatter and presents an irregularly triangular profile, which at this period does not exhibit a segmental character. That part of it adjacent to the auditory vesicle, and which represents the anlage of the ganglion of the root of the glossopharyngeal nerve, is in most cases completely separated from the rest of the crest. It is continued ventralward into the third branchial arch by a looser zone of cells which connects it, just dorsal and caudal to the second gill cleft, with a rounded compact clump of cells forming the future ganglion petrosum. In a similar manner the ganglionic crest of the vagus at its oral end is continuous by means of an ill-defined zone of cells with the anlage of the ganglion nodosum. This ganglion, as can be seen in Figs. 1, 2, 3, and Plate I, is larger than the ganglion petrosum. It is somewhat spindle-shaped, and owing to the branchial arches it takes a caudal direction ending diffusely beyond the fourth arch. Directly over it lies a patch of thickened epidermis and is apparently adherent to it. A careful search was made here and in the ganglion petrosum for evidence of interchange of cells between the ganglia and the epidermis without success. That these ganglia are not simply ventral projections of the ganglion crest is in a degree indicated by the zone of less welldefined tissue, which at this stage separates them from the crest proper.

In the ganglion crest, in addition to the cellular elements, there are a few fibres found at the junction of the crest with the neural tube, thus completing the anlages of the glosso-pharyngeal and vagus nerves. A greater fibre development is found in the caudal part of the ganglion crest of the vagus, where inclosed among the cells, as in a sleeve, is found a well-defined bundle of fibres representing the accessory nerve. This 
bundle makes its appearance at the level of the fourth, fifth, or sixth cervical segment. It consists of fibres which are contributed to it at irregular intervals by the dorso-lateral border of the neural tube. Increasing in size it extends forward, running mesially to the ganglion crest until it reaches the crest of the vagus where the cells of the crest form a sheath for it. The tip of this nerve reaches to the dorsal border of the column of cells which extends from the crest to the anlage of the ganglion nodosum.

The hypoglossal nerve is represented by a row of four or five rootlets, which are in a direct line with those forming the ventral roots of the cervical nerves, and resemble them with the exception that they successively taper off smaller as they become more oral. At this stage they have not grown far enough out for coming together to form a common trunk. The rootlets are bundled together in three divisions, between which are situated the first two occipital myotomes. The third myotome lies between the last division of the hypoglossal and the first cervical nerve.

On looking back at these embryos of the third week, an important feature is observed in the fact that the main motor elements are indicated at this time by the presence of fibres. We find a few fibres in the roots of the ninth and tenth nerves; the trunk of the eleventh is definitely laid down, also the roots of the twelfth and the ventral roots of the spinal nerves. The sensory elements, however, are only indicated by the cellular masses of the ganglion crest.

\section{Embryos of About Four Weeks.}

His Collection, Embryo Br3 .........6.9 $\mathrm{mm}$.

Mall Collection, No. 2............ $7.0 \mathrm{~mm}$.

Gage Collection, Buxton Fmbryo........ $7.0 \mathrm{~mm}$.

(See Figs, 4, 5 and 6.)

In this group of embryos the ganglionic crest is increased in size, but aside from a disproportionate increase in fibre elements, it presents much the same appearance as seen in embryos of three weeks. The flattened dorsal border of the spinal crest still forms a continuous bridge along the tops of the primitive ganglia. Cropping out along this bridge numerous fibroblasts are seen attaching themselves to the spinal cord. These are the primitive dorsal nerve roots. Attention is directed to the later and slower development of these as compared with the ventral roots. Aside from that seen in the dorsal bridge the ganglia show as yet little or no fibre formation. They consist of cells whose round nuclei, scantly sur- 
rounded by protoplasm, are compactly clumped together, the whole forming a row of pillow-like bodies whose ventral borders are lost among the fibres of the ventral roots. It was not possible to determine as to whether or not the ventral borders of the ganglia are involved at this stage in fibroblast formation, and contribute fibres to the nerve root, because of

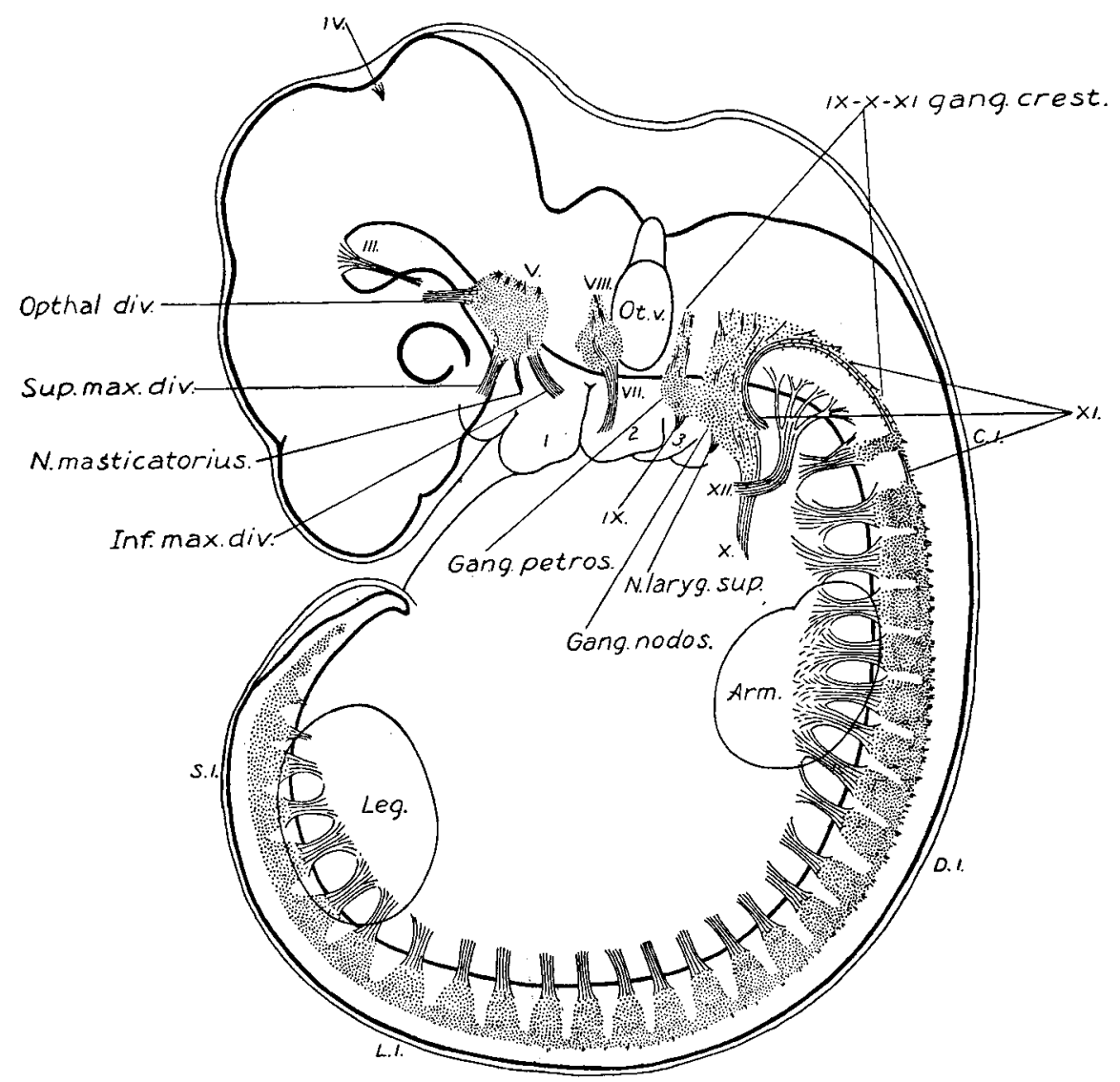

Fro. 4. Réconstruction of peripheral nerves in four weeks human embryo, $6.9 \mathrm{~mm}$. long, His collection Embryo Br3. Enlarged 16.7 diams.

the difficulty of differentiating them from the mesodermal sheath cells of the ventral roots.

The fibres of the spinal nerve roots form compact bundles which branch, as they extend forward, and form intersegmental anastomoses. The profuse anastomosis of the nerve roots from the fourth cervical to the first dorsal segment marks a primitive brachial plexus. (See Fig. 4.) 
The roots of the caudal end of the cord are somewhat tardier in their development, and at this stage the lumbar plexus is only slightly indicated.

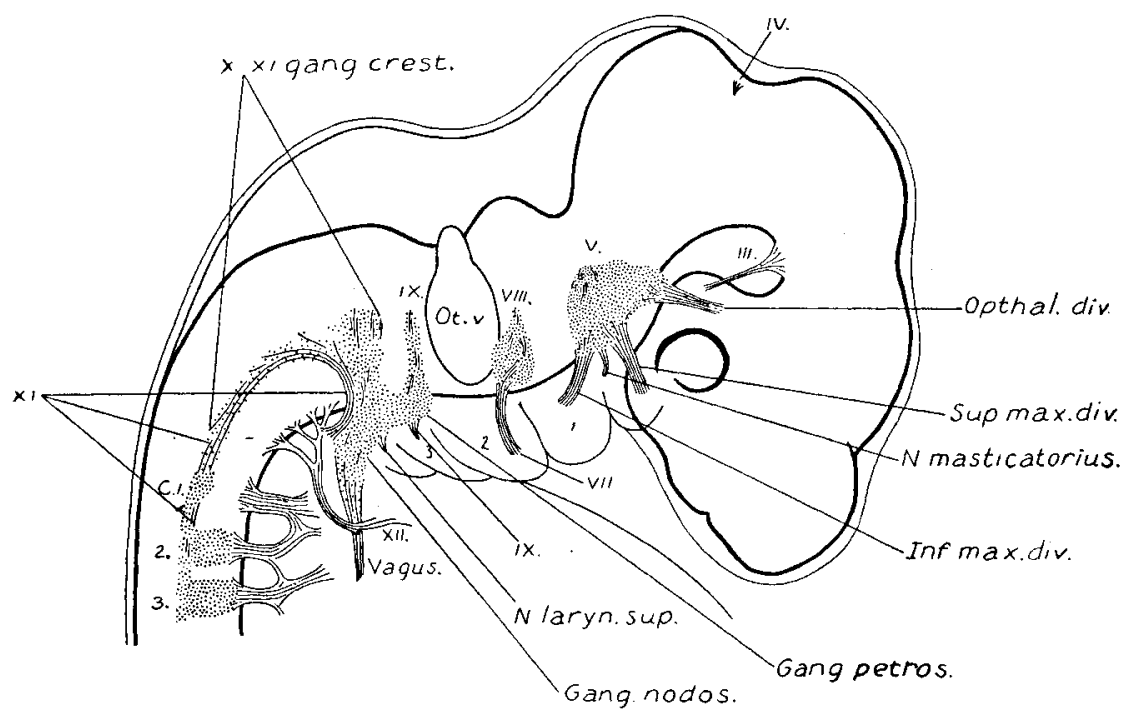

Fig. b. Reconstruction of right side of same embryo shown in fig. 4.

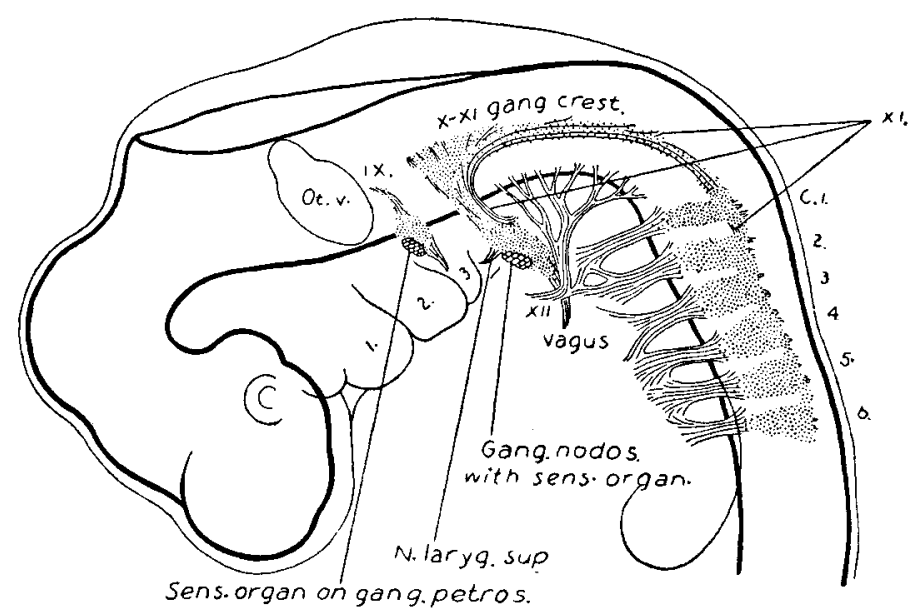

FIG. 6. Reconstruction of peripheral nerves in four weeks human embryo, $7.0 \mathrm{~mm}$. long, Mall collection No. 2. Enlarged 16.7 diams.

On the right side of Embryo Br3 (see Fig. 5), and on the left side of the Buxton Embryo, the first cervical ganglion consists of but a small clump of cells showing no connection with the ventral root, which root, 
however, is well developed. Cases of this kind have in the adult the appearance of entire absence of this ganglion, a point which will be taken up later.

The caudal portion of the ganglion crest of the after-brain is longer and more slender than in the previous stage. The accessory nerve is still ensheathed by the cells of the crest. As it extends forward it turns the curve on the back of the trunk of the vagus, and then freeing itself from the vagus it extends a short distance lateralward and ends abruptly in a mass of condensed mesoderm, the anlage of the $\mathrm{m}$. sterno-cleido-mastoideus. The oral end of the ganglion crest of the vagus is connected with the ganglion nodosum (it will be observed that this ganglion is not considered as simply a part of the vagus crest, which is because of the apparent independence of the two seen in three week embryos) by a compact mass of cells, among which are found some fibres. From the ganglion nodosum there arise two distinct fibre bundles, ventrally the superior laryngeal, and ventro-caudally the main trunk of the vagus, around which winds the hypoglossal nerve.

The rootlets of the hypoglossal nerve unite and form a stem, as in the adult, which seems to be joined by fibres from the first and second cervical nerves at the point where it bends upward to reach the anlage of the tongue. The descending branch of the hypoglossal can be identified on the right side of Embryo Br3 as a short bud at the point where the nerve crosses the main trunk of the vagus. Thus the descendens hypoglossi develops in this case simultaneously with the appearance of anastomoses between that nerve and the upper cervical nerves.

The root of the glosso-pharyngeal nerve is definitely connected with the ganglion petrosum by a fibro-cellular mass. Ventral to the ganglion the trunk of the nerve is represented by a fibre strand extending into the third branchial arch. In Fig. 6 is represented the area on both the petrosal and nodosal ganglia which still remains attached to the overlying thickened epidermis. In Embryo Br3, on both sides of the embryo, the ganglia nodosum and petrosum appear to fuse.

On review of this group it is seen that at the end of the fourth week the ganglion crest is not yet entirely differentiated. We find laid out, however, the roots, the trunks, and the ganglia of the trunks of the ninth and tenth cranial nerves. Further, all the elements of the eleventh and twelfth nerves are present, and the dorsal and ventral roots and the plexuses of the spinal nerves. 


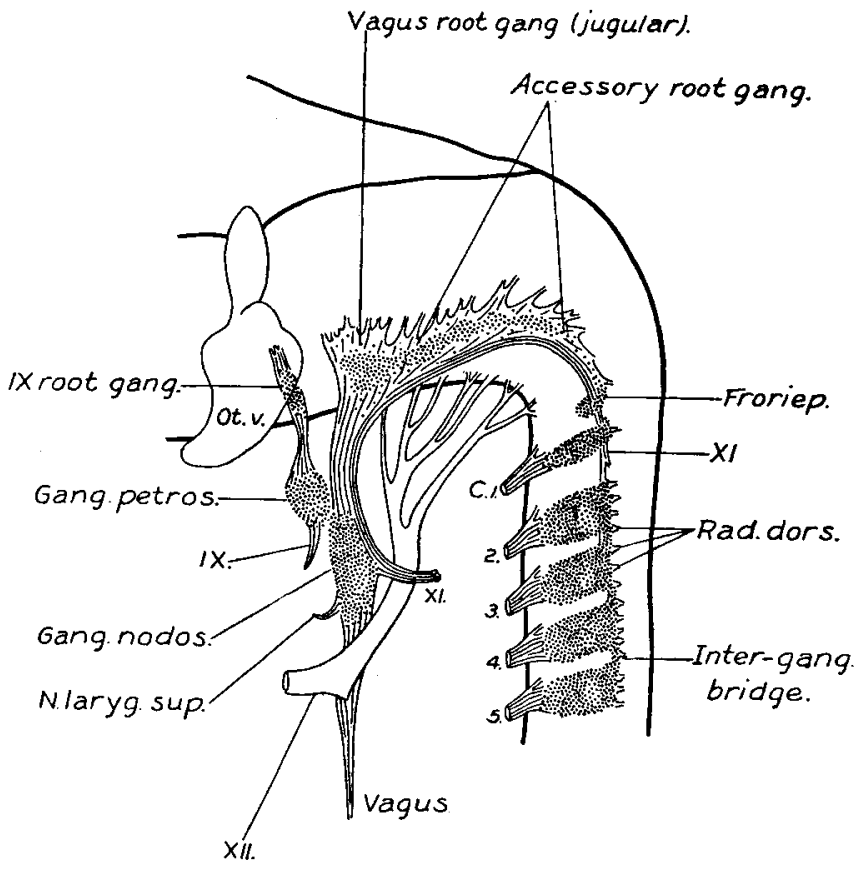

FIG. 7. Reconstruction of peripheral nerves in thirty-one days human embryo, $10.2 \mathrm{~mm}$. long, His collection Embryo KO. Enlarged 16.7 diams.

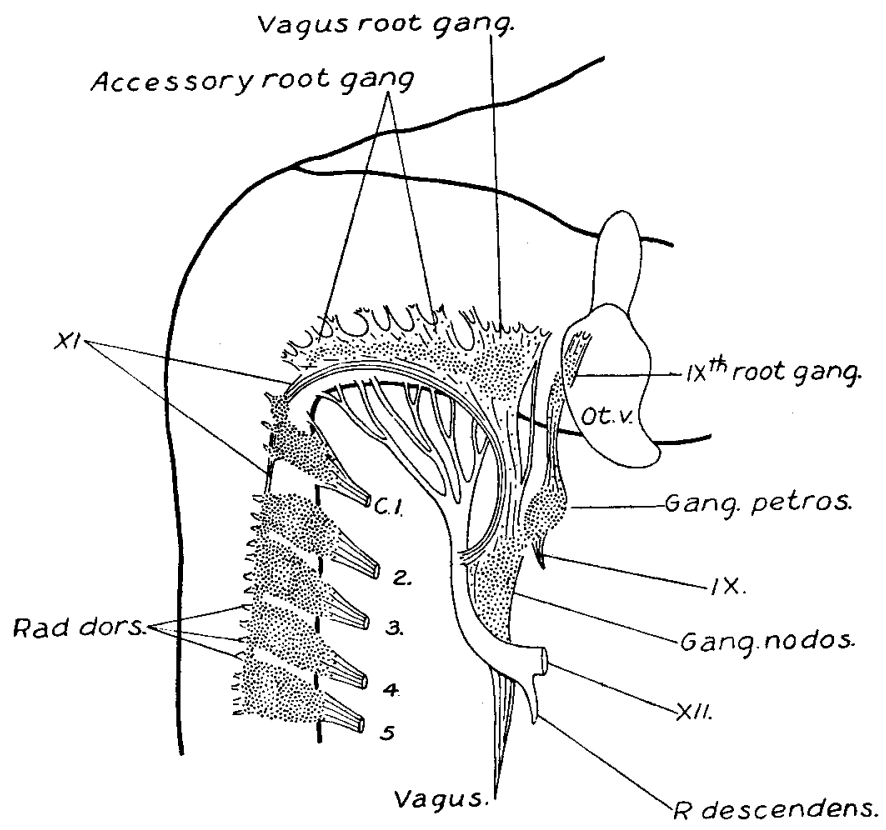

F1Q. \&. Reconstruction of right side of same embryo shown in fig. $\%$. 


\section{Embryos of About Thirty Days.}

Mall Collection, No. $114 \ldots \ldots \ldots \ldots \ldots \ldots 10.0 \mathrm{~mm}$.

His Collection, Embryo Dl............ $10.0 \mathrm{~mm}$.

His Collection, Embryo KO.......... $10.2 \mathrm{~mm}$.

(See Figs. 7, 8, 9 and 14.)

On coming to embryos $1.0 \mathrm{~cm}$. long the final steps in the transformation of the occipital ganglion crest into cranial nerve rootlets and their ganglia may be seen. When Figs. 7 and 8 are compared with Fig. 4, a considerable increase in the actual mass of cells is observed in this region, and also a marked growth of the fibre elements. As this fibre formation

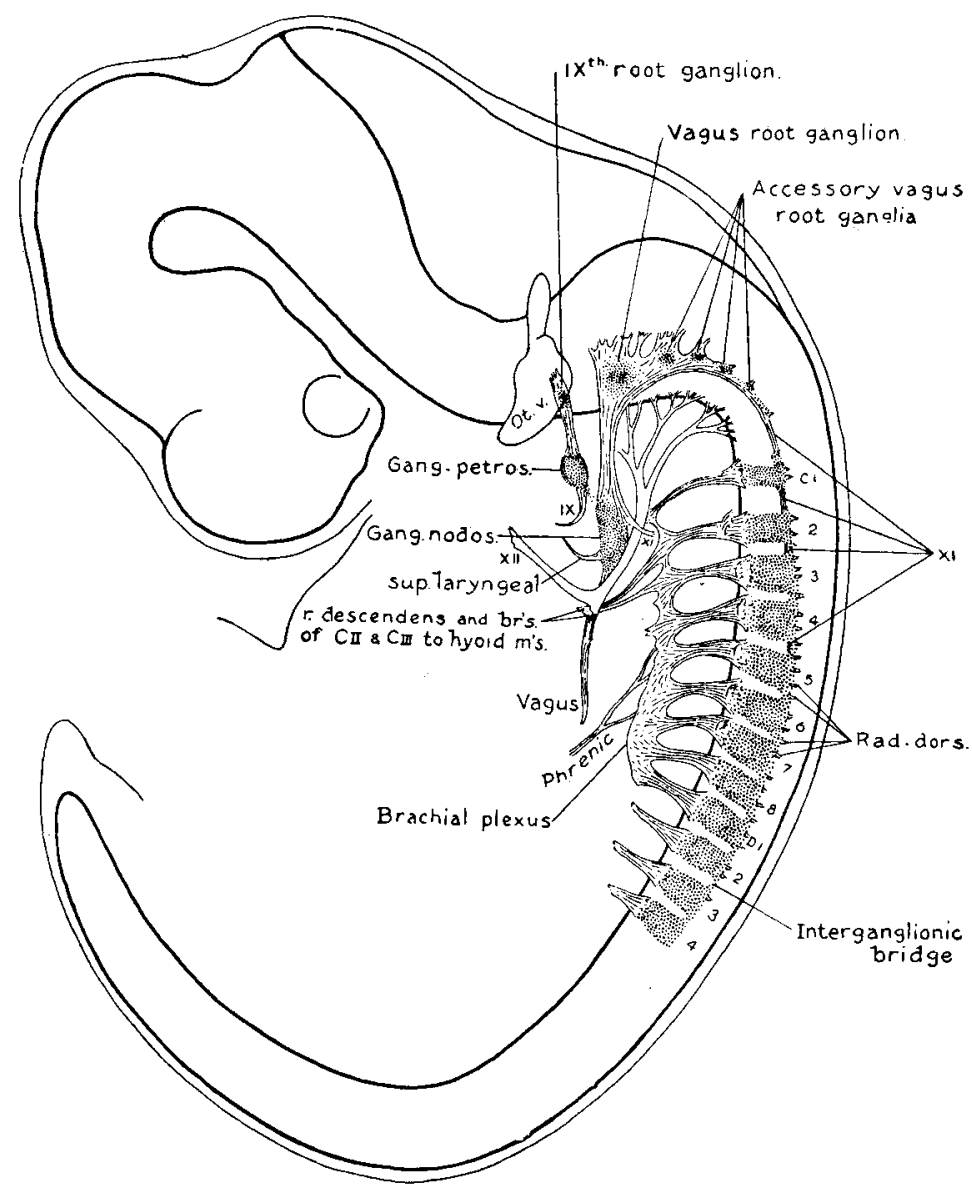

Fra. 9. Reconstruction of peripheral nerves in thirty-one days human embryo, $10.0 \mathrm{~mm}$. long, His collection Embryo DI. Enlarged 16.7 diams, 
continues the cell masses become broken up and separated into ganglionic clumps. Instead of the uniform cellular crest seen in the occipital region in Fig. 4 we find in Fig. 9 a chain of ganglia lying among the rootlets of the ninth, tenth, and eleventh nerves. Just cephalad to the first cervical ganglion, in Fig. 7, is a cell mass which may be regarded, either as a fragment which has become separated off from the first cervical ganglion, or. what is more likely a persistent occipital ganglion (precervical ganglion), such as is found by Froriep, 82 , in the sheep.

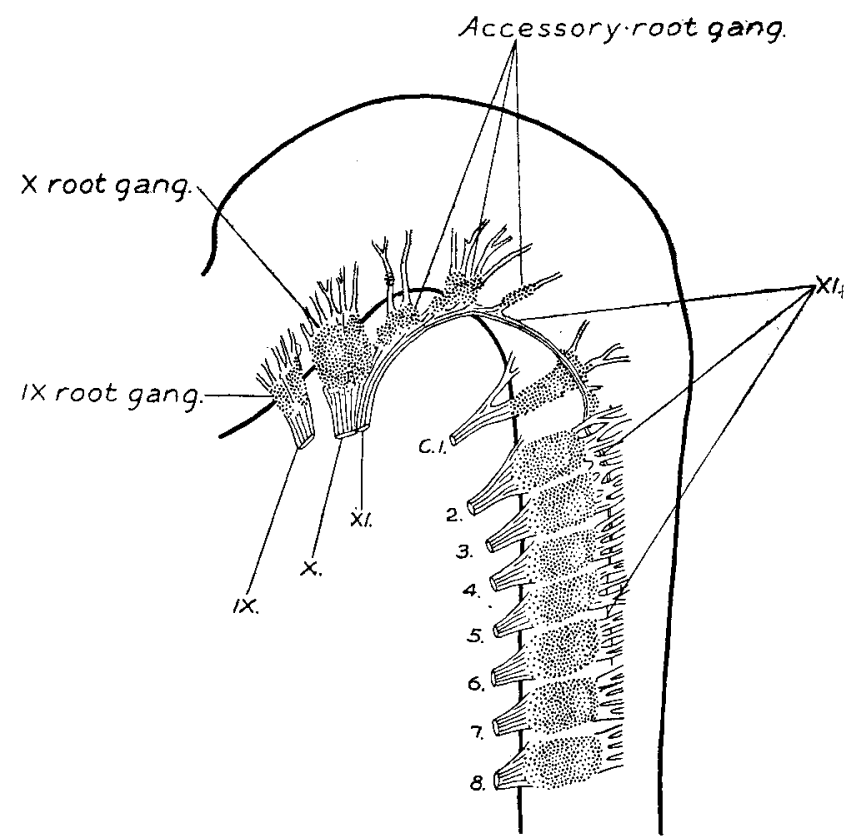

FrG. 10. Reconstruction of peripheral nerves in five weeks human embryo, $13.8 \mathrm{~mm}$. long, Hertwig collection No. 67. Enlarged 18.7 diams.

\section{Embryos of Five to Seven Weeks.}

Hertwig Collection, No. $67 \ldots \ldots \ldots \ldots \ldots . \ldots 13.8 \mathrm{~mm}$.

Mall Collection, No. 144........... $14.0 \mathrm{~mm}$.

His Collection, Embryo FM......... $17.5 \mathrm{~mm}$.

(See Figs. 10, 11, 12 and Plate Ir.)

At the end of the fifth week the ganglion crest is completely resolved into a series of more or less segmental cell masses. The dorsal ridge, which formed an intersegmental bridge across the tops of the spinal ganglia, has disappeared. Simultaneously with the disappearance of this 
structure occurs the outgrowth of the central rootlets of the ganglia. On comparing Figs. 1, 9, and 11 one gets the impression of an actual conversion of the dorsal bridge into the ganglion rootlets. In Fig. 10 the dorsal rootlets have attained a considerable length, and show a tendency toward anastomosis.

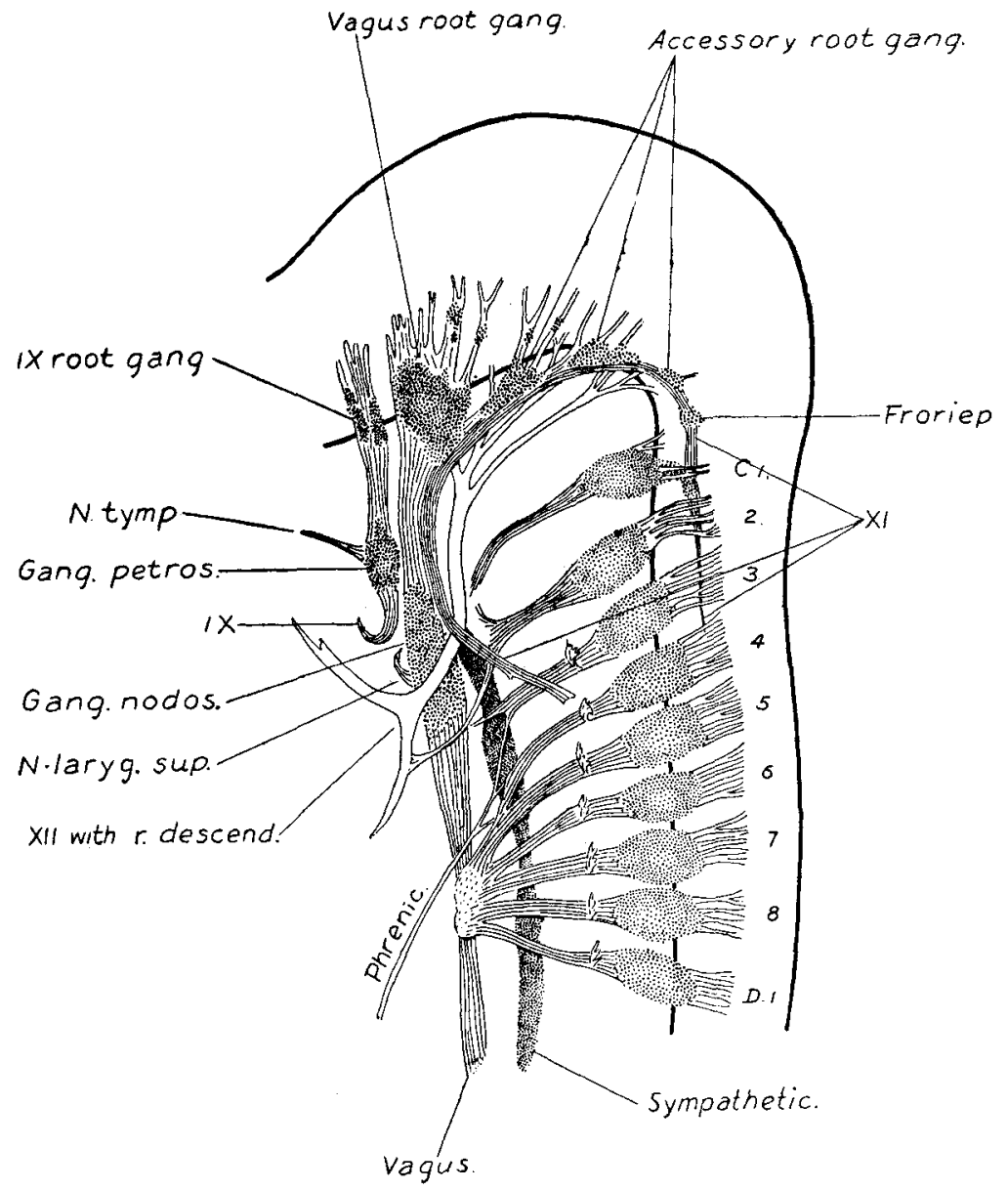

Fia. 11. Reconstruction of peripheral nerves in five weeks human embryo, $14.0 \mathrm{~mm}$. long, Mall collection No. 144. Enlarged 16.7 diams. This drawing is reversed right for left.

The eleventh cranial nerve lies median to the dorsal rootlets, and is attached at irregular intervals to the spinal cord, just ventral to their attachments to the cord. It may run either mesially or laterally to the rootlets of the first spinal ganglion, and is usually adherent to the ganglion itself. Cell masses are found on the trunk of the nerve in this 
region, as though fragments of this ganglion. The close relation between the first cervical ganglion and this nerve serves to explain the conditions found in the adult. Along the more cranial portion of the nerve there is a row of ganglia, the accessory root ganglia, which become successively larger as we go forward, and which form a series with the ganglion jugulare of the vagus. The number of these accessory ganglia is usually three or four principal masses, and in addition there are several smaller clumps scattered among the rootlets. In a series of pig dissections at the corresponding age it was not possible to determine a true segmental order in their formation, and there was no correspondence between these ganglia.and the number of the hypoglossal roots, and they show no connection with them. Thus they are not to be confused with the occipital ganglia of Froriep. The fibre elements of the accessory nerve fuse with those of the vagus. The occurrence of an actual interchange of fibres between them cannot, however, be determined. Leaving the vagus at the ganglion nodosum the accessory can be traced through the $\mathrm{m}$. sternocleido-mastoideus to the $\mathrm{m}$. trapezius.

The relations of the roots, ganglia, and trunks of the ninth and tenth nerves were seen in the previcus stage (Figs. 7, 8, and 9) to have taken on the adult type. In Figs. 11 and 12 the resemblance to the adult conditions is more complete owing to the relative increase of fibre elements. The glosso-pharyngeal nerve arises by several compactly bundled rootlets attached to the neural tube median and caudal to the cartilagenous mass in which the internal ear is embedded. Among these rootlets is the ganglion mass which forms the ganglion of the root or Ehrenritter's ganglion. Beyond this begins the trunk of the nerve, on which is found a second ganglion, the ganglion of the trunk. It is to be remembered that the ganglion of the root and the ganglion of the trunk have developed separately, and have so far remained discrete structures. From the ganglion petrosum is given off ventrally the tympanic branch, or nerve of Jacobson, and caudally the main trunk of the nerve, which hooks inward and forward toward its terminal distribution. The ninth and tenth nerves lie closely together and there is ample opportunity for anastomosis between them, especially between the ganglia of the trunks. It will be recalled that in a younger embryo (Fig. 4) these ganglia were apparently continuous.

The vagus presents the same general type as the glosso-pharyngeus; the root and trunk ganglia are larger, and the trunk itself may be traced down into the thorax.

In Fig. 11 the chain of cervical sympathetic ganglia is indicated, and in Fig. 12 is shown their connections with the spinal nerves. The upper 
portion of this ganglionic chain fuses with the ganglion nodosum, and above this it gives off its branches to the carotid plexus.

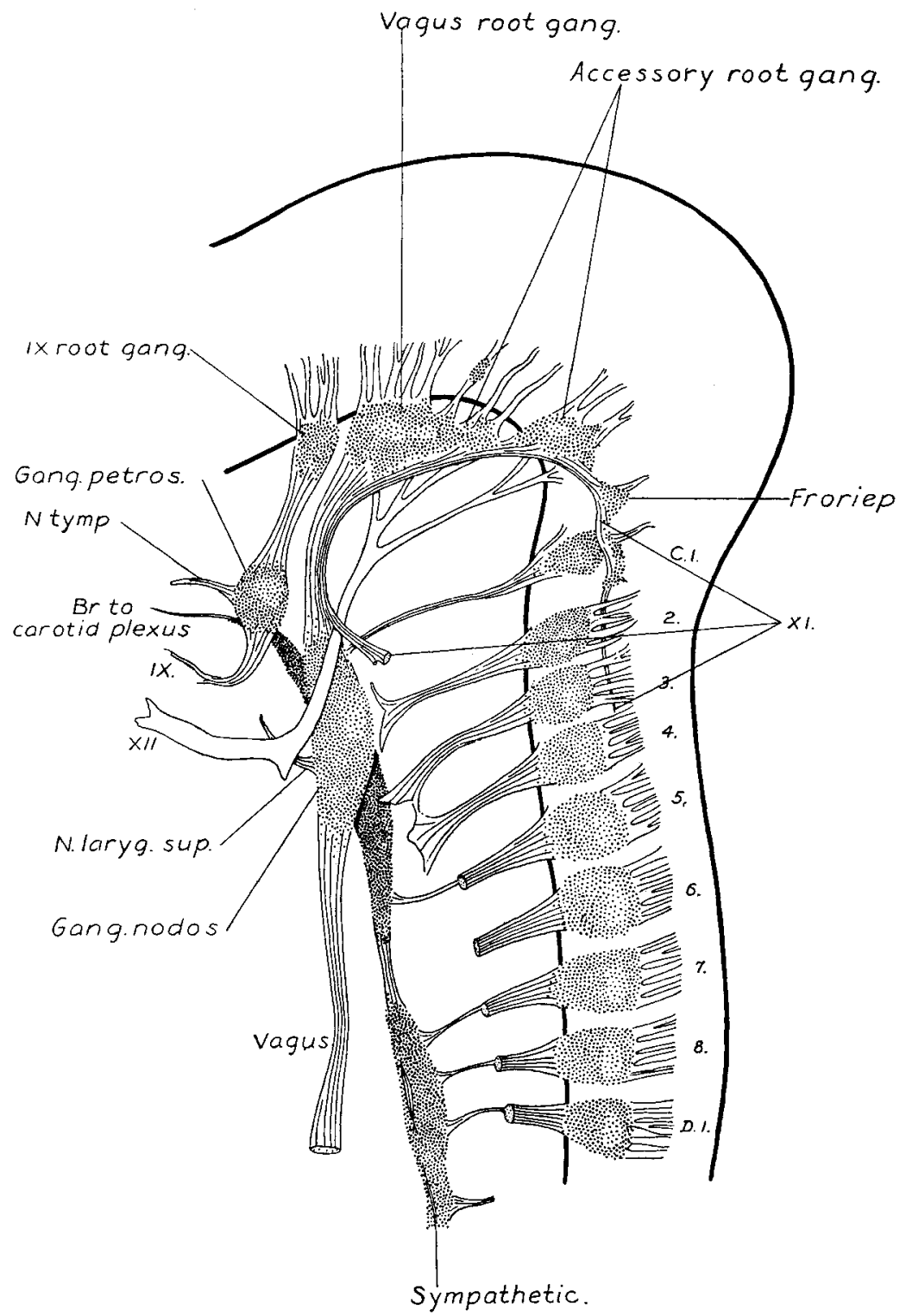

FIG. 12. Reconstruction of peripheral nerves in six weeks human embryo, $17.5 \mathrm{~mm}$. long, His collection Embryo FM. Enlarged 16. $\tau$ diams. 
The principal branches and communications of the hypoglossal and cervical nerves may be distinctly traced in embryos of this size. It will be seen that we thus have in this group the completion of the principal features of both the fibre and the cellular elements of the nerves under consideration; but the picture presented by the adult structure varies somewhat from this, owing to a disproportionate growth of some parts over others, and instead of what here appears as a ganglion cell predominance we meet there with a predominance of the fibre elements.

\section{Embryos of the Second and Third Month.}

Hertwig Collection, No. $161 \ldots \ldots \ldots \ldots \ldots 30.0 \mathrm{~mm}$.

Mall Collection............... $65.0 \mathrm{~mm}$.

(See Plate III.)

During the second and third months there is a progressive growth of the fibre elements with a corresponding stretching-out of the nerve trunks and rootlets, which results in a greater separation of the ganglion masses from one another. The further growth of the ganglia is not uniform; while the ganglia of the trunk of the ninth nerve, and of the root and trunk of the tenth, and the spinal ganglia continue in their development, the ninth root ganglion and the root ganglia of the eleventh reach at this time a point of development at which they remain stationary.

In a reconstruction of the left side of the Hertwig embryo, No. 161, which is not here reproduced, the noticeable change from the conditions shown in Fig. 12 is in the length and sharper definition of the trunk of the accessory nerve. On the trunk of this nerve, between the first cervical ganglion and the ganglion jugulare, there are two root ganglia, and as the accessorius trunk joins the vagus there is a third ganglion mass, which, however, is partly fused with the ganglion jugulare. There are also small clumps of cells among the rootlets of the vagus, as well as on some of the central rootlets of the spinal ganglia.

A dissection of this region in an embryo at the end of the third month is shown in Plate III. There the ganglia of the root of the ninth and the eleventh nerves present very little enlargement. They can be distinguished from the fibre bundles only by a greater opacity, and appear as white nodes in the roots of the respective nerves. The first cervical ganglion is well developed. An arrest in the growth of this ganglion, similar to that in the ganglia just mentioned, might also be expected.

As the nerve fibre growth continues, the last trace of these rudimentary ganglia is lost to the naked eye. In order to determine their ultimate fate a series of sections was made through the structures of this region in an 
adult specimen. This shows the presence of persistent clumps of normal appearing ganglion cells, situated along the trunk of the eleventh and on the roots of the ninth and tenth nerves. A diagrammatic reconstruction of the series is shown in Fig. 13. In this case the first cervical nerve received a communicating branch from the accessory, but macroscopically no ganglion was present. In the series, however, this ganglion is represented by a circumscribed group of cells on the trunk of the accessory. Among the rootlets in the same region are scattered groups of cells which may have been separated off from it. On going further forward other small ganglion groups are met with, either just beneath the connective tissue sheath of the nerve roots, or among their fibres, and usually near

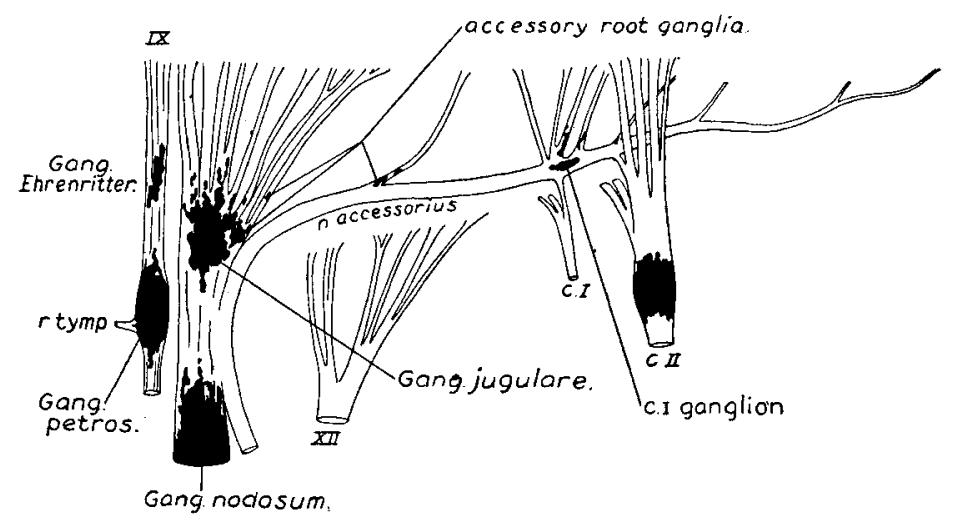

FIG. 13. Diagrammatic reconstruction of ganglion cell masses in peripheral nerves of occipital region in human adult. Compare with Plate IV.

the junction of the roots with the larger trunks. From their position these are considered to be the persistent accessory root ganglia. Although rudimentary in size they are made up of cells which have all the appearances of functionating ganglion cells. It is possible that it is these that provide the sensory fibres for that branch of the accessory which joins with fibres from the vagus to form the pharyngeal branch, in some such way as is schematized in Plate IV.

\section{Development of Individual Nerves.}

It has been seen, in tracing the development of the ganglionic erest of the after-brain, that the ninth nerve stands apart from the more caudal nerves and develops independently, and apparently uninfluenced by them. The tenth and eleventh, in contrast, are parts of a single complex, and cannot be taken up as individual structures without adopting a sepa- 
ration that would be artificial; they will therefore be described together. The hypoglossus and the cervical nerves, where a close relation also exists, will be likewise treated.

The Glosso-Pharyngeal Nerve from the beginning possesses the characteristics of a mixed nerve. In embryos $4.0 \mathrm{~mm}$. long (Fig. 1) it consists of a small clump of ganglionic cells, which can be distinguished in the mesenchyma attached to the neural tube just caudal to the otic vesicle and extending toward the third branchial arch. This group of cells represents the anlage of the ganglion of the root, or Ehrenritter's ganglion. Among these cells are a few fibroblastic processes, which do not belong to them, but arise from cells of the neural tube in the dorsal part of the ventral zone of His, and form the motor elements of the root. The character of this anlage resembles that of the vagus, and may be regarded as a part of the ganglion crest of the after-brain, though it is not continuous with the vagal portion of it. It is evident that this ganglion is not a part which has become separated off from the ganglion petrosum as described by Henle, and others (see Thane, 95), but is an independent structure. Its inconstancy is to be explained by its further development. It reaches a size early in the embryo at which it ceases to further develop, in some embryos earlier than others. The fibre elements, however, continue to grow, and finally overgrow the ganglion and thus cause it to be apparently absent. A similar occurrence will be seen in case of the root ganglia of the accessory nerve.

Ventral to this group of cells is a somewhat larger clump of cells, the primitive ganglion petrosum, which is situated directly beneath the epidermis at the caudal and dorsal margin of the second gill cleft (see Figs. 1,2 , and 3). At this time it is separated from the rest of the anlage of the ninth by a looser zone of cells, and this gives it the appearance of having developed in situ, ratherr than of being a subdivision or bud from the rest of the anlage. It is true that the same appearance might arise from a migration of cells from the latter followed by a proliferation of them at this point. The position of the ganglion petrosum here and in older embryos (Figs. 4, 5, and 6) indicates a close relationship between it and the branchial arches, and the same is likewise true of the ganglion nodosum. In this respect the anlages of the ganglia of the trunks differ from the ganglionic crest proper, or anlage of the root ganglia, which is well removed from the branchial arches and does not show any trace of branchio-meric arrangement. This suggests a difference in origin to exist for the two kinds of ganglia. Another point of difference between the ganglia of the roots and the ganglia of the trunks of these nerves is the 
fusion of the latter with an overlying patch of thickened epidermis, and an apparent absence of such a fusion in case of the ganglia of the roots.

The relation existing between the ganglia of the seventh, ninth, and tenth nerves and the overlying epidermis has been described in mammals by Froriep, 85, and it is regarded by him as the anlage of rudiments of the phylogenetically lost branchial sense organs of Beard, 85, and van Wijhe, 82. In elasmobranchs Froriep, 91, describes later a double line of fusion between ganglia and epidermis, forming the lateral and epibranchial sense organs, which may perhaps be considered as comparable to the ganglia of the roots and ganglia of the trunks. In mammals, however, he had found only a single line of epidermal fusion, that existing over the ganglia of the trunks. In our series of embryos the ganglia of the roots do not seem to take part in the formation of epidermal sense organs, and show no sign of fusion. The condition here resembles that described by Froriep, 85, in his earlier paper. The adherence between the epidermis and the ganglion petrosum and nodosum is indicated in Fig. 6. It is found in all the human embryos studied from 4.5 to $7.0 \mathrm{~mm}$., after which it disappears. This is a somewhat earlier and briefer period than given by Froriep for other mammals. No indication of interchange of cells between ganglia and epidermis could be made out.

The ganglion petrosum in embryos $7.0 \mathrm{~mm}$. long has become connected with the ganglion of the root by a definite strand of mixed fibres and cells, the fibre elements more and more predominating as the embryo becomes older. At the same time a tapering bundle of fibres sprouts from the distal end of the ganglion petrosum, and forms the main trunk of the nerve, the ramus lingualis, and supplies the third arch. Another branch appears in $14.0 \mathrm{~mm}$. embryos, the ramus tympanicus, and extends forward into the second arch. The ganglion thus gives off a branch both oral and caudal to the second gill cleft, and this completes the glossopharyngeus as a typical visceral arch nerve. This was pointed out in mammals by Froriep, 85, who regards the r. lingualis as the post-trematic and the $\mathrm{r}$. tympanicus as the pre-trematic branch.

Communications exist between the ganglion petrosum and the ganglion nodosum in an embryo of $7.0 \mathrm{~mm}$. (Figs. 4 and 5), where they seem almost as a continuous structure; in other embryos of this stage, and younger, they are completely separated. Later (Figs. 7, 8, and 9), following the relative change in position of the adjacent parts which succeeds their unequal growth, these structures are gradually brought close together, and secondary communications are established between them. 
The Vagus Complex includes both the vagus and accessory divisions, the tenth and eleventh cranial nerves, which develop practically as a single structure; though the complex is more spread out than the trigeminal, yet the relation of the accessory to the vagus is embryologically much the counterpart of that of the motor root of the trigeminus to the rest of that nerve. To speak of the two divisions as individual cranial nerves is misleading; perhaps a new terminology should be introduced, which would express more exactly their comparative and embryological relations. Onodi, 02, has suggested the entire removal of the name accessorius as an independent cranial nerve, but does not himself attempt to carry it out. Eventually such a radical attack upon the nomenclature may prove advisable; in this paper, however, whenever it is necessary to distinguish between the different parts of the vagus complex, the original usuage will be retained which is based on the gross anatomy of adult specimens: the term "vagus nerve" will be applied to that portion of the complex represented by the ganglion jugulare with its rootlets, and the peripheral nerve trunk extending from this on which is found the ganglion nodosum; the term "accessory or eleventh cranial nerve," no distinction being made between vagal and spinal portions, will refer to the remainder of the complex situated caudal to this, and includes ganglionated rootlets and the large motor trunk extending peripherally to the sterno-cleido-mastoid and trapezius muscles. In their development it will be seen that both divisions contain motor elements, which spring in a continuous line from the lateral border of the neural tube as far down as the third or fourth cervical segment, and sensory elements which are developed from the cells of the ganglion crest. Later, following its further growth, the oral or vagus division of the complex becomes predominantly sensory, and the caudal or accessory division predominantly motor.

The ganglion crest of the after-brain is apparently directly continuous with that of the spinal cord, and extends from the first or second cervical ganglion to the otic vesicle, an interruption indicating the division between the ninth and tenth nerves. We agree with Dohrn, 01, who describes the vagus crest as forming a unit with the spinal crest, rather than with Froriep, 01, who distinguishes between a ganglion crest of the head and one of the trunk, and states that they do not simply go over into one another, but overlap and run along adjacent to each other, each ending for itself. Evidence of such an overlapping could not be made out.

An embryo of $4.0 \mathrm{~mm}$. represents the youngest stage at which the crest was sufficiently differentiated from the mesoderm for accurate recon- 
struction. The shape of the crest at this time is represented in Figs. 1, 2,3 , and Plate I. In the figures the presence of developing nerve fibres are diagrammatically shown among the cells of the crest. Small bundles of these fibres spring at irregular intervals from the lateral angle of the neural tube and enter the crest. In the caudal two-thirds these fibres join to form a definite strand, which is the primitive trunk of the accessory nerve. This trunk reaches down into the region of the spinal ganglion crest to the level of the third or fourth cervical segment. The fibres do not, however, enter this crest, but run along median to it as far as the first cervical, when they enter the vagus crest as though into a sleeve. In regard to the first cervical a variability is shown, the trunk may run median, lateral, or through it. Forward, in a line with these fibres of the accessory trunk, are found a few others forming small scattered bundles at the head of the crest. That the fibres which are present at this stage are motor may be inferred from three facts: firstly, they spring from the lateral horn region of the neural tube; secondly, there is at this time no apparent fibroblast development in the cells of the ganglion crest; and thirdly, some of them can be followed in their further development until they become known motor elements, as in the case of the main trunk of the accessorius, and as in the spinal cord where the ventral roots at this time are well laid out, though there is as yet no trace of dorsal roots.

Ventral to the head of the vagus crest, and partially separated from it by a looser zone of cells, is found a second ganglionic mass, the primitive ganglion nodosum, the relation between which and the crest repeats the condition found between the ganglion of the root and the ganglion of the trunk of the glosso-pharyngeus, evidence of independence being here equally strong. As was there pointed out, the ganglion nodosum is closely associated with the development of the more caudal branchial arches. The patch of thickened epidermis over the ganglion, as in Fig. 6, represents an epibranchial sense organ. A complete segmentation of the ganglion nodosum, which might be expected in considering this anlage as the morphological equivalent of a series of gill cleft ganglia, is not found, though the cells show at first a loose irregular grouping, which represents perhaps a branchio-meric tendency. The laryngeal branch of this ganglion is present in $7.0 \mathrm{~mm}$. embryos, and forms the principal nerve to the fourth branchial arch. The main vagus trunk is differentiated at about the same time and is seen sprouting out from the distal end of the ganglion.

At the end of the first month (Figs. 7,8 , and 9) the cellular column between the ganglion nodosum and the ganglion crest is converted into a fibrous trunk. At this time the ganglion crest, besides an increase in 
size, is modified in form by the development of numerous rootlets attaching it to the neural tube, and by an irregular clumping together of the cells of the crest, forming ganglion masses along the main trunk of the accessorius, which now lies at the ventral border of the crest. The rootlets which are developed at this time are in part sensory, as is evidenced by comparison with the dorsal spinal roots. The division of the crest into ganglion masses is accompanied by a rapid development of fibres between its cells, and it is probable that the growth of these fibres is the cause which spreads the cell masses apart into separate clumps. Such a separation into clumps radically differs from true segmentation, the latter does not seem to occur here. As the fibre growth continues the ganglion masses become more and more separated, and finally the crest becomes completely converted into a series of discrete ganglia (Figs. 10 and 11). The most oral one is the largest and forms the vagus root ganglion, the ganglion jugulare. Caudal to this, successively diminishing in size, is a chain of three or four accessory root ganglia, which extend backward along the accessory trunk until they meet the cervical ganglion series. In the vagus complex the ganglia diminish in size in the caudal direction, while in the spinal series the reduction in size is in the oral direction; this fact enables one to distinguish between accessorius root ganglia and precervical (Froriep) ganglia. Those ganglion masses found adherent to the accessorius between the first and second, and the second and third cervical ganglia, as in Figs. 10, 11, and 12, are developed from the spinal crest, and represent nodules derived from the spinal ganglia and which have become separated off. Formed similarly to these, are found isolated masses on the rootlets of the jugular ganglion.

The vagus division of the complex at this stage (embryos of $14.0 \mathrm{~mm}$.) therefore consists of mixed motor and sensory rootlets, the ganglion jugulare, and the nerve trunk on which is situated the ganglion nodosum, giving off a laryngeal branch as well as communicating branches to the ganglion petrosum. The accessory division begins at the third or fourth cervical segment. Its trunk runs median to the dorsal roots, except at the first cervical where it may be lateral. It is attached to the neural tube by mixed rootlets, on which are found a varying number of ganglia. The trunk after an arched course joins the vagus division, but the greater portion of it soon leaves the vagus and extends to the shoulder region and supplies the sterno-cleido-mastoid and trapezius muscles.

The essential features of embryos of the fifth and six week, Figs. 11 and 12 , will be observed to be the same as in older embryos and in the adult, Plate III and Fig. 13. The existing difference may be accounted 
for by the disproportionate growth of the fibre elements over that of the cellular elements, and of some of the cellular masses over that of others; most of the cell masses persist, but some of them early reach a point at which they remain stationary, such as the accessorius root ganglia, and sometimes the first cervical. Following the increase in fibre growth they become buried among the rootlets or on the accessorius trunk, and though not seen by the naked eye they can be seen on section. Fig. 13 represents a case in which the first cervical ganglion was macroscopically absent, but microscopically it is present as a large clump of normal appearing ganglion cells within the sheath of the accessorius trunk.

Anastomoses between the first cervical and the trunk of the accessory nerve in the adult have excited much interest. Among others they have been studied by Kazzander, 91, and later by Weigner, 01. A study of Weigner's drawings shows that the accessory nerve of one side has no. constant relation to the accessory nerve of the other side in the same individual; they bear themselves as independent structures, and his 37 examinations may therefore be considered as 74 individual cases. By re-analyzing Weigner's cases in this manner instructive data on our present subject have been obtained. They show that the relation in the adult of the first cervical to the accessorius is as follows:

$19 \%$-First cervical ganglion and dorsal root are present, and do not anastomose with the accessorius.

$19 \%$-First cervical ganglion and dorsal root are macroscopically absent.

$62 \%-$ Various kinds of anastomosis between the first cervical dorsal root and the accessorius. In many of these cases the ganglion is macroscopically absent.

These anastomoses are doubtless to be explained on embryological grounds. The relative position of the two structures at the beginning of connective tissue formation would determine their permanent relations. If they lie in contact at that time they become permanently adherent. Secondarily, when the dorsal roots become thus entangled in the accessory trunk, as they are apt to in case of the first cervical, they are dragged along out of their original position by later growth and the consequent relative shifting of all of the structures in that region. Further irregularities in their course may be caused by the accessory which, being laid down earlier than they, would have the tendency to guide the impinging dorsal rootlets out of the direct centripetal line to the neural tube, and along its own trunk, either forward or backward. A diagram showing some of these variations is reproduced in Plate IV. In the same diagram is shown the hypothetical course of some of the other fibres of the acces- 
sory. No motor fibres are represented as running from the accessory to the larynx, the absence of such fibres having been well established by the work of Onodi, 02, and others, and the clinical observations of Seiffer, 03. Fibres of the accessory doubtless join the trunk of the vagus, but they are omitted here for sake of simplicity.

The Hypoglossal Nerve can first be made out in embryos at the end of the third week, at which time it consists of loose fibre strands which can be traced between the occipital myotomes springing from the ground plate of the neural tube and extending a short distance in the mesenchyma (see Fig. 1). These rootlets are formed in three or four segmental groups and develop in the same line with the ventral roots of the cervical nerves. During the fourth week they grow forward and fuse in a common trunk. At the end of the first month this trunk has passed around the ganglion nodosum, and curves around the sinus cervicalis mesially and orally to reach the anlage of the floor of the mouth. A week later its principal branches of distribution are indicated.

As the hypoglossus crosses the ganglion nodosum it gives off the ramus descendens, which is first definitely seen in embryos $1.0 \mathrm{~cm}$. long. Mall, 91, and Piper, 00, report its absence in embryos $7.0 \mathrm{~mm}$. and $6.8 \mathrm{~mm}$, respectively. His, 88, pictures a long r. descendens in $\mathrm{Br} 3$ (6.9 mm.). In a reconstruction of the same embryo, made since then by the author (see Fig. 4), this is not seen. There is, however, on the opposite side (Fig. 5) a slight indication of a beginning branch. At the time the descendens is developed the opportunity for communication between the hypoglossus and the upper two or three cervical nerves already exists; that is to say, the terminal fibres of the latter end in brush-like tufts in close contact with the former. The amount of interchange of fibres cannot be accurately traced, but it is evident that the character of the descendens is dependent on the nature of the contribution of fibres from the cervical nerves. The course in the development of this cervical anastomosis is as follows (compare Figs. 3, 4, 6, 9, and 11): The fibres of the hypoglossal and the upper cervical nerves start out perpendicularly from the neural tube, and due to the curve of the latter they come together like spokes in a wheel, and then grow along adjacent to each other into the premuscle tissue of Froriep's schulterzungenstrang; when the formation of the nerve sheaths begins, adjoining fibres become thereby more or less bound together, and as the individual tongue and hyoid muscles draw apart these nerves are led out into an open plexus, the adult arrangement of which and its variations has been described by Holl, 7\%. The exact formation of this anastomosis must depend on the position of the fibres at the time the sheaths are formed. This introduces a variability which 
might account for the different arrangements found by Holl. A further source of variation is presented by slight differences in the division line between the rootlets of the hypoglossus and the first cervical; the fibres destined for the $\mathbf{r}$. descendens, for instance, may be either picked up with the more caudal rootlets of the hypoglossal, when there will be little or no communication between the hypoglossal and the first cervical, or on the other hand may be picked up with the first cervical and reach their destination through anastomosis with the hypoglossal. Thus in embryo No. 144 of the Mall collection (Plate II) on the right side the first cervical contributes no fibres to the hypoglossal and descendens, while on the left side a large communicating bundle exists between them.

In the early stages the rootlets of the hypoglossal present a close similarity to the ventral roots of the spinal nerves, and now are generally considered as a cranial continuation of them; the nerve being thus derived from the fusion of three or four segmental spinal nerves, which in the course of phylogenesis have become enclosed in the cranium. In the hypothetical ancestor the segments of the nerve belonged to the trunk, and possessed, in addition to the ventral roots, both dorsal roots and ganglia, the latter becoming subsequently reduced coincidently with the invasion of the vagus group into this region. Strong support to this view was given by Froriep, 82, who in the hoofed animals found persistent dorsal roots and ganglia belonging to one or two of the more caudal divisions of the nerve. Similar precervical ganglion masses and rootlets were found in the rabbit, cat, and mouse by Martin, 91, and Robinson, 92 . The former describes five hypoglossal ganglia in cat embryos, of which he finds only the most caudal one to persist. He thus apparently includes those that in our series of reconstructions are considered as accessory root ganglia, which we think have a different phylogenetic significance. In the human embryo His, 88 , describes an abortive precervical ganglion, and names it after Froriep. Inasmuch as he considers the hypoglossus to belong phylogenetically to the vagus rather than to the spinal nerves, he is inclined to doubt a relation between the Froriep ganglion and the hypoglossus. In our reconstructions a typical ganglion may be seen in Figs. 7 and 11 . The former is the same embryo pictured by His, and does not essentially differ. On the other side of this embryo, Fig. 8, the first cervical ganglion creeps forward a short distance along the accessorius tract, and thus represents what may be styled as a precervical tendency. An interesting case is shown in Fig. 2, where the first cervical ganglion is divided in two equal parts, each having its own ventral root. With further growth they would have become separated, as the spinal ganglia do, and then we should have in the more oral one 
a typical Froriep ganglion with a ventral root that would have doubtless joined with the hypoglossus fibres. In Fig. 9 a slight indication of a ganglion is present, though it is not labelled in the diagram. In such cases one cannot say whether it belongs to the spinal group or to the accessorius root ganglia of the cranial group. These two seem to develop from the same crest, and it could be expected that the oral tendency of the former and the caudal tendency of the latter might cause in some cases a fusing of the two; such an instance is seen in Fig. 12. Where the retrogression of the spinal elements is advanced, the Froriep ganglion is absent, and the first cervical also then shows abortive tendencies. If Fig. 5 is compared with Fig. $\%$, it will be seen that there the spinal reduction extends an entire segment further caudad; instead of a rootless Froriep ganglion, as in Fig. 7 , there is in Fig. 5 a rootless first cervical ganglion.

It is evident that there is a great irregularity in the degree of reduction of the occipito-spinal dorsal roots and ganglia in different individuals. By comparing individuals of different ages we cannot therefore estimate the retrogression undergone in the development of a single individual; one cannot say, for instance, that because a Froriep ganglion is present in an embryo of $7.0 \mathrm{~mm}$. and is not present in another embryo of $14.0 \mathrm{~mm}$. that it has in the latter case disappeared. It was found in case of the accessory root ganglia that ganglion masses once present persist throughout life, though they may early reach a point beyond which they do not further develop. The same is doubtless true as regards the Froriep ganglion.

\section{Comparative Morphology.}

In considering the phylogenetic significance of the nerves of the occipital region it becomes apparent that we are here dealing with structures of two different sources; on the one hand, the cranial nerve elements represented by the glosso-pharyngeus, the vagus, and the accessorius-a portion of the vagus, and on the other hand the elements of spinal origin, the upper cervical nerves and the hypoglossus. The literature concerning the comparative anatomy of these structures is voluminous, and particularly their involvement in the various theories proposing a segmental origin of the vertebrate skull. A complete review of this literature and discussion of the morphological bearing of the cranial nerves is given by His, 87, and again later by Rabl, 92. Since then has appeared the important work of Fürbringer, 97, supplemented by the embryological investigations of Braus, 99, and Froriep, 02. Mention should also be made of the work done on the accessory nerve by Lubosch, 99. The general facts as known may be stated as follows: 
In the lower fishes the cranial and spinal elements are clearly separated and their territories do not overlap; a line may be drawn oral to which all the nerves are cranial and caudal to which all are spinal. In the phylogenesis, owing to a caudal encroachment of the skull into the spinal region, the more oral of the spinal nerves become included in the head region and have special foramina of exit. Those that are thus assimilated by the selachii have been styled by Fürbringer as occipital nerves, and those assimilated in addition later by the holocephali are called occipito-spinal nerves. With this assimilation, however, the spinal and cranial elements are still discretely separated by a transverse line of demarcation. There is no actual overlapping of the two until we come to the sauropsida. Here and in all higher vertebrates, accompanying the conversion of certain vagus gill muscles into the trapezius and sternocleido-mastoideus, the cranial elements ( $i$. e. vagus complex) make a caudal invasion into the spinal region, in such a manner that the accessory portion of the vagus is found wedging itself in between the ventral and dorsal spinal roots mesial to the ganglia, gaining attachments to the cord just ventral to those of the dorsal spinal roots.

In the human embryo the different stages of this invasion cannot be demonstrated. Either the early steps are not repeated in the embryological history of higher types, or it may be, as McMurrich, 03, suggests, that the derivation of such structures cannot be demonstrated ontogenetically because the phylogenetic stages occur while the structures are still in an undifferentiated state. In the embryos studied, as soon as the nerve elements can be distinguished, they have their final relative position, and the accessorius is found extending well down into the cervical region. Its caudal end is indicated by " $\mathrm{E}$ " in Figs. 1, 2, and 3. The vagus-accessory anlage is, in all three instances, about of the same size. Some variation exists in the extent of overlapping of the cranial and spinal parts, as is evidenced by the variation in distance between the ganglion jugulare and the first cervical ganglion. It is doubtless a variation of the individual, and is of the same character as the variation occurring in the distance over which the accessory nerve extends into the cervical region of the adult. In Fig. $\mathbf{1 4}$ is shown the wedge-like invasion of the cranial nerve elements into the spinal territory. The figure is a diagrammatic profile reconstruction of an embryo one month old. The gill arches, vertebral skeleton and muscular apparatus, and spinal and cranial nervous systems are plotted out with view to a comparison of their relative pasitions. It shows clearly the impossibility of drawing any transverse line through the body, oral to which everything would be cranial, and caudal to which everything would belong to the spinal 
system. The behavior of the nervous system adds to the irregularity in the line of junction between the head and trunk.

As the accessorius wedges itself into the spinal territory there occurs a progressive retrogression of the more oral spinal elements, resulting in the disappearance of the dorsal roots and ganglia of the occipito-spinal nerves, these being the first nerves encountered. The ventral roots of these nerves persist and join to form the hypoglossus, and supply the

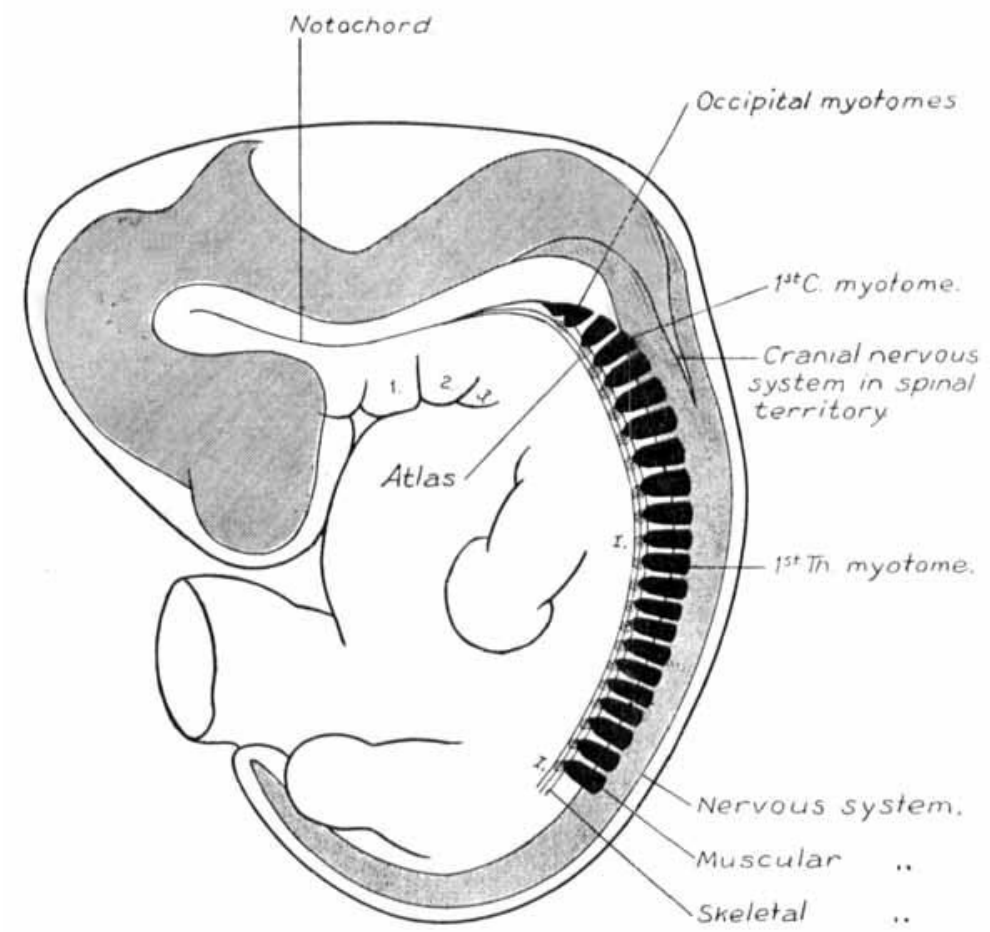

Fra. 14. Diagrammatic reconstruction of one month human embryo, $10.0 \mathrm{~mm}$. long. Mall collection No. 144. Enlarged 9 diams.

tongue, which in the meantime has been acquired in the floor of the mouth. In some of the domestic animals (rabbit, pig, cow, and sheep) one or two of the more caudal of the occipito-spinal dorsal roots and ganglia persist as was pointed out by Froriep, 82, whose name they have received. In man the most caudal ganglion occasionally persists, but it is usually without any connection with a corresponding ventral root; in one case, however, a Froriep ganglion with ventral root was present, and doubtless would have joined with the hypoglossus as its most caudal root. 
Often the connection between the ventral root of the first cervical and its ganglion is also missing in man, and the ganglion rudimentary and found only on section. These rudimentary ganglia during embryonic life become adherent to the invading cranial member, the accessory nerve, and though all connection with the ventral root is absent, they still may functionate by sending their fibres forward or backward along the accessorius, in the latter case joining a more caudal nerve. Although the first cervical ganglion, and perhaps a precervical or Froriep's ganglion may thus lie in the tract of the accessorius, it is to be remembered that embryologically they are separate structures, the one cranial and the other spinal. The apparent relation between the two is only due to the fact that in the early stages they lie closely together, and become adherent in this position.

In addition to these occipito-spinal (precervical, hypoglossal, or Froriep's) ganglia, there are found in the human adult other rudimentary ganglia situated along the accessory nerve, which are of cranial origin, and similar to the root ganglion of the vagus. These are the accessory root ganglia; they form, in the six weeks embryo, a series of ganglionic clumps, which extend caudalward from the ganglion jugulare, successively diminishing in size, along the tract of the accessory nerve attached to its rootlets. A true segmental arrangement of them does not seem to prevail in the human embryo, and the same is true in dissections of pig embryos. The ganglion jugulare continues to develop, but these accessory ganglia early reach a size beyond which they do not further develop. They, however, do not undergo retrograde metamorphosis; at any rate not completely, for evidence of them may still be found in the human adult.

The root ganglia of the ninth, tenth, and eleventh nerves develop from a ganglion crest which has an appearance and history analogous to that from which the spinal ganglia develop. The ganglia which form on the trunks of the vagus and glosso-pharyngeus apparently develop independently from that crest, and they differ from the ganglia of the roots in being branchio-meric, and in possessing definite traces of rudimentary sense organs.

The hypoglossus in contrast to the tenth and eleventh nerves, which show no trace either in rootlets or ganglia that they were ever formed from a series of segmental nerves, presents a distinct segmental grouping of its fibres, as may be seen in Plate I and Fig. 1. 'This fact, added to its resemblance in its early stages to the ventral roots of the cervical nerves in point of origin from the same column of cells, its relation to the myotomes, and the occasional presence of a Froriep ganglion, offer conclusive evidence that this nerve is the equivalent of three or four ventral 
roots of phylogenetically lost occipito-spinal nerves, which have become fused into a single trunk.

\section{Conclusions.}

1. The tenth and eleventh cranial nerves are parts of the same complex, both possessing mixed motor and sensory rootlets, together with root ganglia derived from the same ganglionic crest.

2. During the progress of development of this vago-accessory complex the cephalic end becomes predominantly sensory, and the caudal end becomes predominantly motor and also more spread out. This produces a difference in the appearance of the two portions which has resulted in their being considered as two independent structures. The cephalic portion forms the vagus or tenth cranial nerve, and the caudal portion the n. accessorius Willisii or eleventh cranial nerve. The old nomenclature is retained, and in so doing the term eleventh cranial nerve is used as synonymous with $n$. accessorius vagi plus n. accessorius spinalis.

3. The root ganglia of the tenth and eleventh cranial nerves do not present a definite segmental arrangement.

4. The trunk ganglia of the ninth and tenth cranial nerves (gang. petrosum and gang. nodosum) when first jdentified are not definitely connected with the root ganglia of the same nerves, and they differ from the root ganglia in having an arrangement segmentally related to the gill arches, and possessing rudimentary sense organs.

5. The ganglia found on the rootlets of the eleventh cranial nerve are the counterpart of the root ganglion or jugular ganglion of the tenth. They do not reach the high development of the latter, though traces of them persist in the adult. They are to be distinguished from the precervical ganglion of Froriep, which represents an extra spinal ganglion.

6. The eleventh cranial nerve extends caudalward into the spinal region to the third or fourth cervical segment, in some cases further; the extent and variation in the embryo is the same as in the adult. The caudalward invasion of this nerve is phylogenetic, and not ontogenetic.

\%. The hypoglossal nerve in young embryos closely resembles the ventral roots of the adjacent cervical nerves, and is segmentally continuous in the same line with them. That a phylogenetic retrogression has removed the dorsal roots, which they seem to have at one time possessed, is evidenced both by the occasional presence of a Froriep ganglion and by cases in which the retrogression has gone still further caudalward, and has removed the dorsal root of the first cervical nerve.

8. The ramus descendens hypoglossi is developed in some cases before the hypoglossus has received any connecting branches from the cervical 
nerves; in other cases such connections are formed coincident with or before the $r$. descendens appears. A variable relation exists between the r. descendens and the communicating cervical branches.

9. The ventral roots of the spinal nerves are developed earlier than the dorsal roots. Similarly in the cranial nerves those portions generally recognized as motor are differentiated into fibre paths earlier than the sensory elements.

\section{LIST OF REFERENCES.}

Balfour, F. M., 76.-On Development of the Spinal Nerves in Elasmobranch Fishes. Phil. Trans., Vol. CLXVI.

Bardeen, C. R., 03.-The Growth and Histogenesis of the Cerebro-Spinal Nerves in Mammals. Amer. Jour. Anat., Vol. 2.

BEARD, J., 85.-The System of Branchial Sense Organs and their Associated Ganglia in Ichthyopsida. Quart. Jour. Micr. Science, Vol. 26.

Braus, H., 99.-Beiträge zur Entwicklung der Muskulatur u. des peripheren Nervensystems der Selachier. Morph. Jahrbuch, Bd. 27.

Chraruar, G., go.-Le Developpement des Nerfs Vague, Accessoire, Hypoglosse et Premiers Cervicaux chez les Sauropsides et chez les Mammiferès. Archiv. Ital. d. Biol., Tome XIII.

Dogiec, A. S., 03.-Das periphere Nervensystem des Amphioxus. Anat. Hefte, Arbeiten, Bd. 21.

DoHRN, A., or,-Studien zur Urgeschichte des Wirbelthierkörpers. Mitth'l. Zool. Station zu Neapel, Bd. XV.

Froriep, A., 82.-Ueber ein Ganglion des Hypoglossus etc. Arch. f. Anat. u. Phys. Anat. Abth.

- 85.-Ueber Anlagen von Sinnesorganen am Facialis, Glossopharyngeus und Vagus. Arch. f. Anat. u. Phys. Anat. Abth.

- or.-Ueber die Ganglienleisten des Kopfs und des Rumpfes und ihre Kreuzung in der Occipitalregion. Arch. f. Anat. u. Physiol. Anat. Abth.

- 02.-Zur Entwickelungsgeschichte des Wirbeltierkopfes. Verhandl. d. Anat. Gesell. Halle.

FürbRivaER, M., 97.-Die Spino-Occipitalen Nerven der Selachier u. Holocephalen und ihre vergleichende Morphologie. Festschr. f. Gegenbaur.

Gegenbaur, C., 72.-Kopfskelet der Selachier. Leipzig.

Harrison, R. G., or.-Ueber die Histogenese des peripheren Nervensystems bei Salmo salar. Arch. f. Mikr. Anat., Bd. 57.

Hatscher, B., 92.-Die Metamerie des Amphioxus und des Ammocoetes. Weiner Anatomen Kongress, Anat. Anz. Verhandl., Bd. 7.

His, W., 87.-Die morphologische Betrachtung der Kopfnerven. Arch. f. Anat. u. Physiol. Anat. Abth.

- 88.-Centralen $u$. peripherischen Nervenbahnen beim menschlichen Embryo. Abhandl. math.-phys. Cl. Kgl. Sachs. Ges. Wiss., Bd. 14.

HoLL, M., 77.-Beobachtungen über die Anastomosen des Nervushypoglossus. Zeitschr. f. Anat. u. Entw., Bd. 2. 
116 Development of Occipital Nerves in Human Embryos

Kazzander, J., 9x--Ueber den N. access. Willisii und seine Beziehungen zu den oberen Cervicalnerven. Arch f. Anat. u. Physiol. Anat. Abth.

Lewis, F. T., 03.- The Gross Anatomy of a 12. mm. pig. Amer. Jour. Anat., Vol. 2.

Luвоsсн, W., 99.-Vergleichend-anatomische Untersuchungen über den Ursprung und die Phylogenese des N. accessorius Willisii. Arch. $\mathbf{f}$. Mikr. Anat. u. Entwick. Bd. 54.

MaIL, F. P., 9I.-A Human Embryo 26 days old. Jour. of Morphol., Vol. 5.

- o3.-Note on Collection of Human Embryos. Johns Hopkins Hosp. Bull., Vol. 14.

Martin, P., 9r.-Die Entwicklung des neunten bis zwölften Kopfnerven bei der Katze. Anat. Anz., Bd. 6.

McMurnich, J. P., 03.--The Phylogeny of the Forearm Flexors. Amer. Jour. Anat., Vol. 2.

Minot, C. S., 92.-Human Embryology. Wm. Wood \& Co., N. Y.

ONodi, A., 02.-Der Nervus accessorius und die Kehlkopfinnervation. Arch. Laryngol. u. Rhinol., Bd. 12.

PIPer, H., oo.-Ein menschlicher Embryo von $6.8 \mathrm{~mm}$. Nackenlinie. Arch. f. Anat. u. Physiol. Anat. Abth.

RABL, C., 92.-Ueber die Metamerie des Wirbeltierkopfes. Verhandl. d. Anat. Gesell. Wien.

Ransom and Thompson, 86.-On the Spinal and Visceral Nerves of Cyclostomata. Zool. Anz., Bd. 9.

Robinson, A., 92.- Observations on Development of Posterior Cranial and Anterior Spinal Nerves in Mammals. Report British Assoc. for Advancement of Sci., Edinburgh.

SetFFer, 03.-Die Accessorius-Lähmungen bei Tabes dorsalis. Berlin. Klin. Wochenschr., 40-41.

Thane, G. D., 95.-The Nerves. Quain's Anatomy, Vol. III, Part II.

VAN WiJHE, 82.-Ueber die Mesodermsegmente u. Entwicklung der Nerven des Selachierkopfes. Verhandl. koninkl. Akad. Wetenschappen., 22 Deel. Amsterdam.

Weianer, K., or.-Beziehungen des Nervus accessorius zu den proximalen Spinalnerven. Anat. Hefte, Arbeiten (Merkel-Bonnet), Bd. 17. 


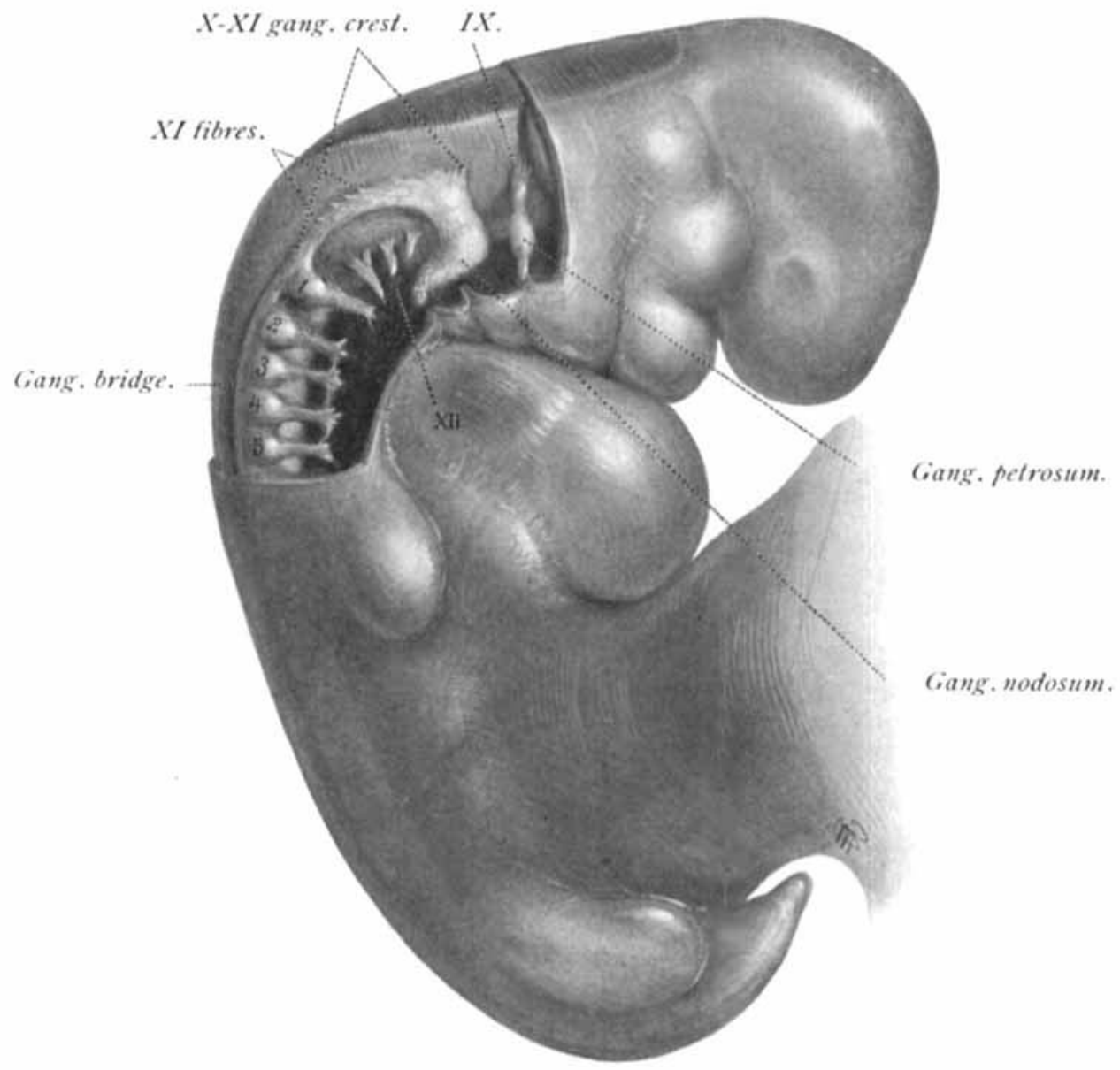

PROFILE RECONSTRUCTION OF PERIPHERAL NERVES IN THREE WEEKS HUMAN EMBRYO, 4.3 MM. LONG, MALL COLLECTION No. 148. ENLARGED ABOUT 25 DIAMETERS. THE THIRD DIMENSION FOR THIS DRAWING WAS OBTAINED FROM A CLAY MODEL, AND THE SHADING IN PART COPIED FROM A PIG EMBRYO OF SAME STAGE. 


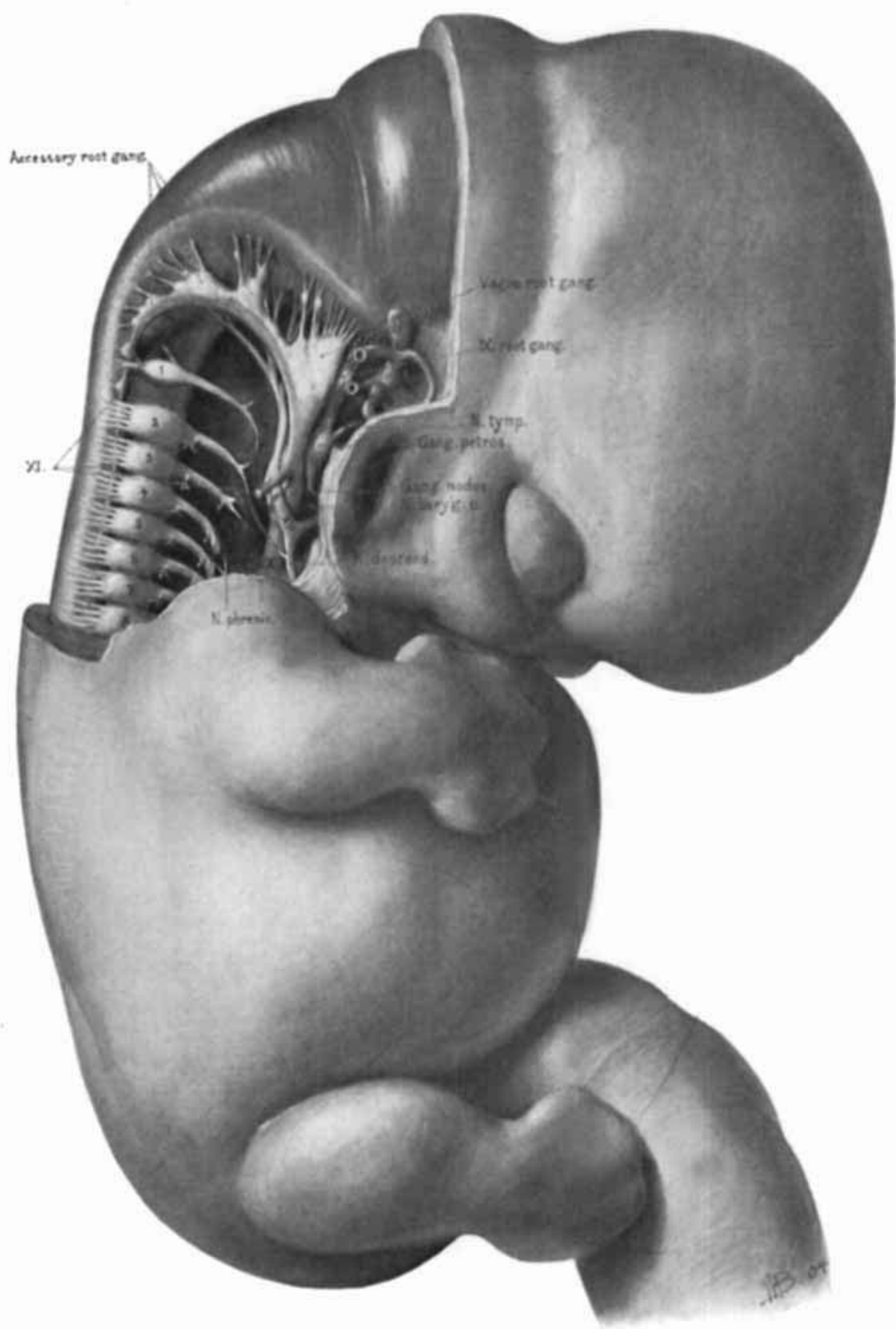

WAX PLATE RECONSTRUCTION OF PERIPHERAL NERVES IN OCCIPITAL REgION OF FIVE WEEKS HUMAN EMBRYO, 14.0 MM. LONG, MALL COLLECTION No. 144. ENLARGED ABOUT 25 DIAMETERS. 
GEORGE L. STREETER

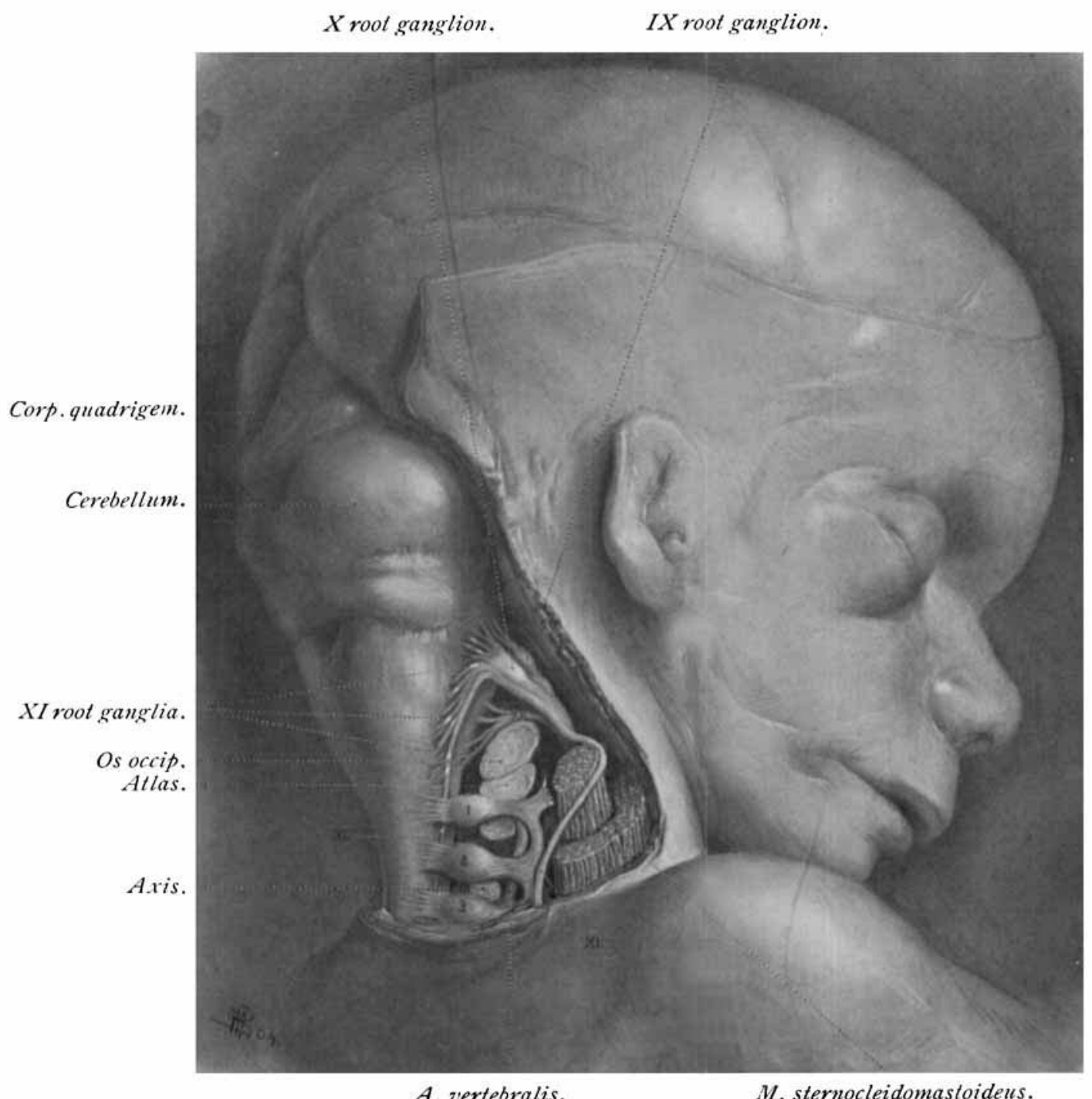

A. vertebralis.

M. sternocleidomastoideus.

DISSECTION OF NERVES IN OCCIPITAL REGION OF THREE MONTHS HUMAN EMBRYO, 65.0 MM. LONG, MALL COLLECTION. ENLARGED 4 DIAMETERS. 


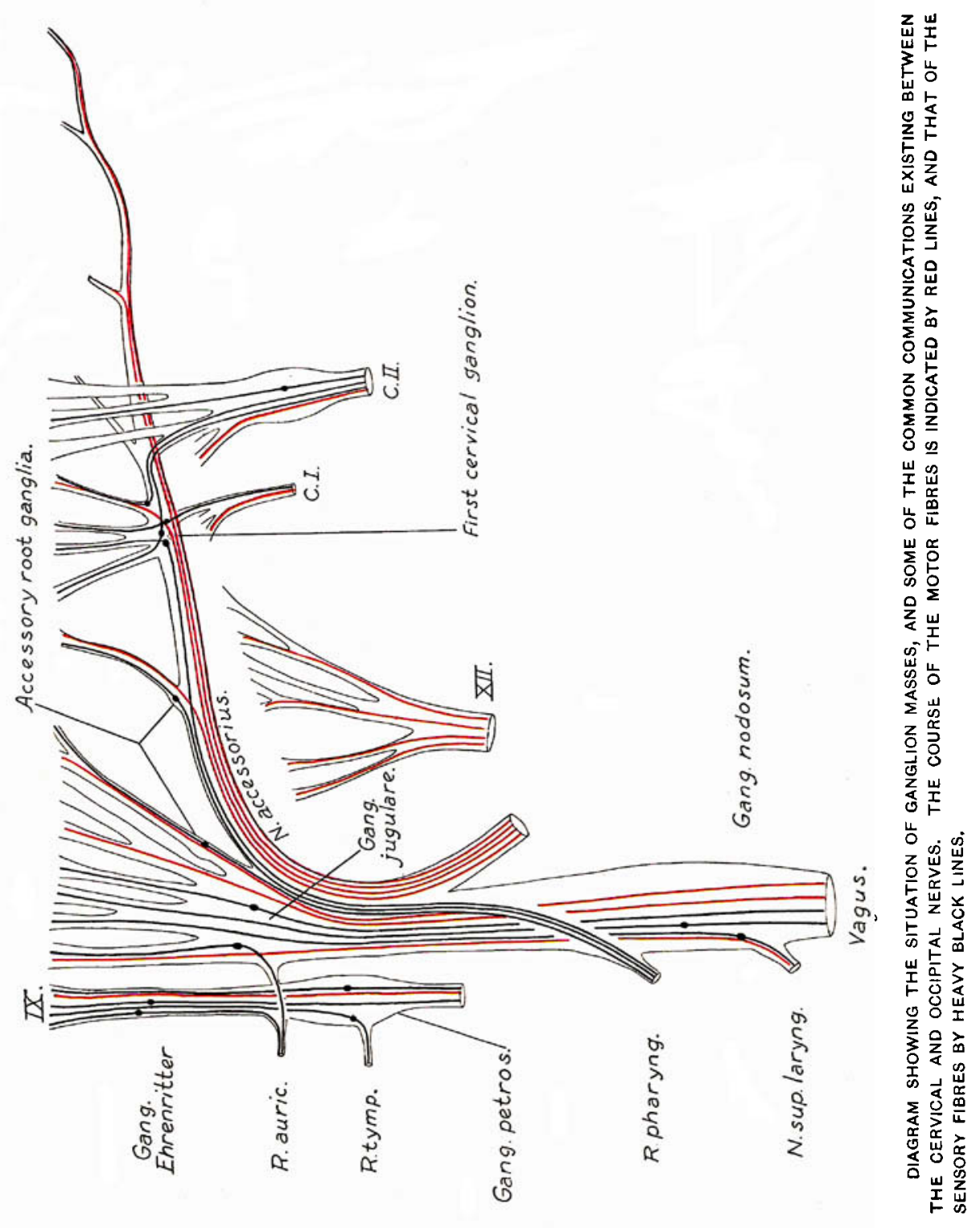

